\title{
REFLECTIONS ON COVID-19, INSURANCE, BUSINESS INTERRUPTION, SYSTEMIC RISK, AND THE FUTURE
}

\section{Reflexiones sobre la COVID-19, los seguros, la interrupción de los negocios, el riesgo sistémico y el futuro}

\author{
Robert H. Jerry, II \\ University of Missouri School of Law (USA) \\ E-mail: jerryr@missouri.edu
}

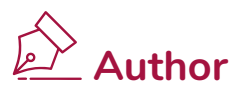

(ㄱ) Abstract

The COVID-19 pandemic is a major loss event for the insurance industry. This chapter begins with an overview of the pandemic's most significant insurance implications. Because business interruption has been the most prominently discussed of these impacts, the second part of this chapter takes a closer look at business interruption insurance. This part describes how markets for this coverage are structured in the U.S., and then undertakes a detailed analysis of one of the most common business interruption policy forms, demonstrating that some aspects of this form, insofar as pandemic-caused business interruption is concerned, were not drafted with utmost precision. This part also discusses how disputes over common policy language used in the U.S. have unfolded, both in legislatures and the courts. The chapter concludes with a discussion of the future of insuring the business continuity risk. It explores the limitations of private markets, the role of government, and the need for an overarching strategy for pandemic risk management, within which insurance would play a significant but partial role.

La pandemia de la COVID-19 ha supuesto uno de los eventos con mayores pérdidas para la industria de los seguros. Este artículo comienza con una visión de las implicaciones más significantes que la pandemia ha supuesto para los seguros. Debido a que la interrupción del negocio ha sido el más destacado de estos impactos, en la segunda parte se analiza más de cerca el seguro de interrupción del negocio. Esta parte describe cómo se estructuran los mercados para esta cobertura en los EE. UU. Se realiza un análisis detallado de uno de los contratos de politica de interrupción de negocios más comunes, demostrando que algunos aspectos de este contrato, en lo que respecta a la interrupción de negocios causada por una pandemia, no fueron redactados con la máxima precisión. Esta parte también analiza cómo se han desarrollado las causas sobre el lenguaje de politica común utilizado en los EE. UU., tanto por los legisladores como por los tribunales. El articulo concluye con una discusión sobre el futuro de asegurar el riesgo de continuidad del negocio. Explora las limitaciones de los mercados privados, el papel del Gobierno y la necesidad de una estrategia global para la gestión del riesgo pandémico, dentro de la cual los segurosjugarian un papel significativo pero parcial. 
COVID-19; business interruption; continuity risk; risk management

COVID-19; interrupción de negocio; continuidad del riesgo; gestión de los riesgos

The numbers are staggering by every measure. As of 26 January 2021, less than one year after COVID-19 began to spread rapidly throughout the world's population, there are over nearly 100 million confirmed cases in almost 200 countries and over 2.1 million deaths (Visual and Data Journalism Team, 2021, 26 January) The International Monetary Fund forecasts that the global economy will shrink by 4.4 percent in 2020 (International Monetary Fund, 2020, October, p. 8$)^{1}$, the deepest global recession since World War II despite unprecedented government efforts to mitigate the economic shock. According to the World Bank, the worldwide economic contraction is likely to cause global extreme poverty to rise for the first time in over twenty years, pushing perhaps as many as 150 million people into extreme poverty (World Bank, Press Release, 2020, 7 October). In the United States, which leads the world in coronavirus deaths and infections (The Guardian, 2021, 26 January) ${ }^{2}$ the estimated cumulative financial costs of the pandemic in terms of lost output and health reduction are estimated in one study at more than $\$ 16$ trillion, or approximately 90 percent of U.S. annual gross domestic product (Cutler \& Summers, 2020).

Given that the COVID-19 pandemic has stressed virtually every facet of human engagement around the world, it should surprise no one that the pandemic is a major loss event for the insurance industry.

The literature on COVID-19's implications for the insurance business is already voluminous, and detailed discussion of these implications cannot be accomplished in any format shorter than a treatise. Thus, this commentary must necessarily have more limited ambitions. It is divided into three parts. Part I provides an overview of commonly recognized insurance impacts of the pandemic. These impacts are significant in almost all lines, but, at least presently, and assuming the virus does not become more aggressive and more lethal, these impacts do not threaten solvency. No doubt because of the staggering economic carnage that the pandemic has caused, the most prominently discussed insurance product is the one directed at the risk of disruption of business continuity. Thus, Part II takes a closer look at business interruption insurance. This Part examines its purposes, explains the common formulations of business interruption coverage in policy forms, and provides a detailed analysis of a commonly used, representative business interruption form used in the U.S. This Part also discusses how disputes over common policy language used in the U.S. have unfolded, both in legislatures and the courts. Part III looks to the future. This Part makes predictions about the contours of the revenue-replacement insurance market of the future, comments on the limitations of private markets in dealing with "difficult" and "systemic" risk, and concludes by discussing the

1 This is actually a $0.8 \%$ improvement from what the IMF forecast in June 2020. See Amaro (2020, 13 October).

2 Reporting the U.S. having over 25.2 million cases and over 420,000 deaths, and leading the world in total cases, total deaths, and total cases and deaths the previous two weeks. 
role of governments in developing a coherent risk management strategy for future pandemics, which, unfortunately, are certain to occur, even if their timing is uncertain.

\section{Insurance Implications of COVID-19}

It is obvious that the pandemic's financial shocks have implications for the balance sheets of insurance companies in every product line. In some lines, this is the most severe implication of the pandemic. The value of insurers' invested assets is negatively impacted by declines in and the increased volatility of equity markets and by changing bond yields driven by shifting default risk and low interest rates (OECD, 2020, 2 July, p. 5). The pandemic also triggers stressors for the quality of assets in insurers' portfolios, including commercial mortgage loans, mortgage-backed securities, municipal bonds, and corporate bonds ${ }^{3}$. Yet the risk of mass insurance company insolvencies is low; as one commentary puts it, "the industry remains well capitalized to meet policyholder obligations according to analysts, with analyst estimates putting the industry solvency ratio between 180\% (JPM) and 190\% (Deutsche Bank)" (Richter \& Wilson, 2020, p. 190). This could change, however, if, as one assessment put it, economic conditions evolve into a "situation of a sustained period of difficult financial markets or global recession” (Byrne, et al., 2020).

On the claims side of the business, the extent of adverse impacts depends on the product line, as discussed below.

\subsection{Mortality and Morbidity Risk}

COVID-19 has caused unanticipated and significant increases in mortality ${ }^{4}$; whether this is significant for the actuarial assumptions built into current life insurance policies is a complicated question. A recent study published by the Geneva Association opines that it almost certainly will not (Schanz, Eling, Schmeiser, \& Braun, 2020, p. 22). As the report explains, the high quality of insurers' mortality data has enabled effective modeling of mortality risk, and data from the 2002-2004 SARS and the 1918-1919 influenza pandemics have enabled companies to produce elaborate pandemic-stress scenarios. These models predict, and experience thus far has not contraindicated, that direct mortality and morbidity consequences for the insurance industry will be limited (Richter \& Wilson, 2020, pp. 183-192).

Multiple variables drive these results. Medical underwriting tends to identify lower-risk, healthier policyholders who have lower mortality rates when they confront a novel pathogen. The demographics of insurance purchasers tends to align with access to superior health care services and therapeutics, which improves mortality (Schanz et al., 2020, p. 22). To the extent the business of life insurers involves the sale of annuities ${ }^{5}$, increased mortality will reduce the

3 See, e.g., BDO US (2020, April); Kirti \& Shin (2020, 20 June); Byrne et al. (2020).

4 For example, although COVID-19 did not begin to surge in the U.S. until mid-March, by late September it was clear that the coronavirus will be the third leading cause of death in the U.S. for 2020, after heart disease and cancer. See Ramirez, Amin \& Cox (2020, 21 October).

5 See Insurance Information Institute (2020); in the U.S., the underwriting of annuities accounted for $48 \%$ of life/annuity direct premiums written in 2019. 
exposures of insurers in annuity markets, which offsets adverse claims experiences in life insurance. It is reasonable for life insurers to anticipate revenue declines, given that the economic recession accompanying the pandemic is likely to increase lapse rates when some insureds find themselves unable to continue to pay premiums, and increased unemployment will reduce the amount of employer-provided life insurance in force. But these effects, assuming the accuracy of the projected trajectory of COVID-19, will not be catastrophic for the life insurance industry.

Health insurance is very different from other kinds of insurance products because of the large government presence as a direct provider, the diminished relevance of fortuity, and strong social insurance elements in national systems (Jerry \& Richmond, 2018, \$ 64C). In the U.S. in particular, health insurance is unique, relative to the health care finance and access systems of other nations, in its complex mix of federal and private coverage and in its longstanding status as one of the most controversial subjects on the national political landscape. An emerging serious impact of the pandemic in the U.S. devolves from the fact that most citizens under age 65 obtain health insurance through employment; estimates vary, but it is apparent that millions of people have lost or will lose coverage because of unemployment associated with the pandemic-caused economic contraction ${ }^{6}$. In addition to problems for consumer access to needed health care, this has direct implications for health insurers' premium collections. Health insurers face unprecedented challenges with respect to claims reserves, premium collectability, premium deficiency reserves, and premium calculations (due to uncertainties about treatment and testing costs for COVID-19) (Okpewho, 2020, August). That being said, the Geneva Association's recent report concludes that "[f]or health insurers, [...] pandemic risk poses no fundamental insurability challenges", (Schanz et al., 2020, p. 23) largely because "the decline in [expenditures for] medical care for non-COVID conditions and routine or elective procedures has more than offset the impact from COVID-19 claims" (Schanz et al., 2020, p. 23).

\subsection{Liability Risk}

\subsubsection{General and Products Liability Insurance}

Liability insurance is implicated by third-party claims for bodily injury filed against policyholders for failing to mitigate the risk of contamination and to give adequate warnings about these risks. The most likely commercial situation where such claims will be asserted involves alleged negligence in protecting customers or invitees from exposure to the virus. It is possible that similar negligence claims might arise in personal, household settings as well. As a substantive matter, these claims face substantial legal hurdles, including meeting the plaintiff's burden to prove that the infection occurred at the defendant's business establishment or residence and was caused by the defendant's negligent (or reckless) acts or omissions. But unless insurers can establish that liability policies provide no coverage, these claims will need to be defended pursuant to the insurers' duty to defend. Since 2008, a communicable disease ex-

6 See Gangopadhyaya, Karpman, and Aarons (2020, 17 September); Sloan, Duddy-Tenbrunsel, Ferguson, Valladares, and Kornfiel (2020, 16 September): more than 12 million forecast to lose health insurance as a result of the pandemic, including more than 5 million Black and Hispanic. 
clusion has been available for addition by endorsement to the Commercial General Liability (CGL) form (Stanovich, C. F. 2020, June), and this exclusion, when it is present, is likely to resolve the coverage question in the negative in many cases.

An additional substantial mitigating variable for liability insurers is the fact that, as of the end of October 2020, sixteen states in the U.S., with more likely to follow, have enacted liability shield laws for businesses against COVID-19 liability claims (Nishamunda \& Young, 2020, 29 October) The statutes vary as to content, but the common denominator is that they protect businesses and their employees from civil suits related to actual or potential exposure to COVID-19. When liability does not exist, the insurer has no duty to indemnify. Most complaints in notice-pleading jurisdictions and well-pleaded complaints in fact-pleading jurisdictions will trigger the insurer's duty to defend, but shield statutes will facilitate dismissals of many of these claims, and summary judgments are likely in cases that survive a motion to dismiss.

Other standard provisions in liability insurance forms will be pertinent to negligence claims asserted against policyholders. It is likely that exposures to COVID-19 will be deemed "occurrences" or "accidents", thereby satisfying the typical triggering language in the liability forms. However, the "expected or intended" exclusion, which removes coverage for damage or injury expected or intended from the viewpoint of the insured, is likely to come into play due to insurers asserting that a reasonable insured would or should have expected the exposure given the existence of pandemic conditions. Also, in some states, the pollution exclusion has been interpreted broadly enough to potentially include viruses and bacteria within its reach, thereby negating coverage.

As for products liability, it is inevitable that some persons will seek to assert claims against providers and manufacturers of provider protective equipment, diagnostics, treatments, and vaccines. In 2005, however, Congress enacted the Public Readiness and Emergency Preparedness (PREP) Act ${ }^{7}$, which provides sweeping tort immunities to such providers and manufacturers and preempts any and all state laws to the contrary ${ }^{8}$. The emergency declaration that invokes the applicability of these immunities to COVID-19 pandemic claims was issued by the Secretary of Health and Human Services on 17 March 2020, and has been amended on three occasions since then?

\footnotetext{
7 Pub. L. 109-148, Div. C, 119 Stat. 2818 (30 Dec. 2005). The immunity provision is codified at 42 U.S.C. $\S$ 247d-6d (2020).

8 The scope of the immunity provision is broad, as it applies to "any claim for loss that has a causal relationship with the administration to or use by an individual of a covered countermeasure, including a causal relationship with the design, development, clinical testing or investigation, manufacture, labeling, distribution, formulation, packaging, marketing, promotion, sale, purchase, donation, dispensing, prescribing, administration, licensing, or use of such countermeasure". 42 U.S.C. $\$ 247 \mathrm{~d}-6 \mathrm{~d}(\mathrm{a})(2)(B)$. "Covered countermeasure" is defined broadly to include "products", which includes drugs, biological products, devices, respiratory protective devices, and countermeasures such as vaccines. See $\$ 247 \mathrm{~d}$-6d(i). For more discussion, see Congressional Research Service (2020, 21 September).
}

9 For links to the 17 Mar. 2020 declaration and the amendments, see U.S. Dept. of Health \& Human Services, Public Readiness and Emergency Preparedness Act, https://www.phe.gov/Preparedness/legal/prepact/Pages/ default.aspx (accessed 19 Nov. 2020). 
As of the end of November 2020, few cases have been brought in the U.S. by policyholders against insurers seeking relief from denials of coverage under liability policies. However, only a few months have passed since COVID-19 surged and created the possibility of claims and coverage disputes. Thus, it is too early to assume that a large number of liability claims will not be asserted, but the hurdles to asserting successful claims against policyholders and the barriers many policyholders will face in establishing coverage suggest that liability insurance markets will not have significant disruptions resulting from COVID-19.

\subsubsection{Directors and Officers Liability Insurance}

Shareholders are likely to make claims against corporate directors and officers for economic losses resulting from inadequate responses to COVID-19, such as management's failure to adhere to government recommendations or requirements, to prepare or implement adequate contingency plans, and to fail to disclose properly the risks posed by the pandemic to a company's performance. Thus, directors and officers $(\mathrm{D} \& \mathrm{O})$ liability insurance policies will become very relevant in the world of COVID-19.

Most D\&O liability policies exclude coverage for bodily injury, but the wording of these exclusions vary, with some being broader than others (Davis \& Grossman, 2020, 20 March). Many of these exclusions speak to liability for bodily injury, which is different from liability for economic loss arising out of management's failure to anticipate the risk of bodily injury (DiMugno, 2020, June). Some policies include "sickness" or "disease" within the definition of bodily injury (Donald, 2020, 20 April) but, again, liability for sickness or disease is not the same as liability for economic loss arising out of sickness or disease. On the other hand, exclusions drafted to exclude any claim "based on, directly or indirectly arising out of, or relating to actual or alleged bodily injury" could be interpreted to have a broader range of application, and thus a narrowing effect on coverage (Davis \& Grossman, 2020, 20 March). The meaning of these exclusions in the context of COVID-19 will no doubt be litigated in future cases.

The essential point in this product line is that directors and officers are accountable for how they manage their company, regardless of the nature of the business challenges they face, and $\mathrm{D} \& \mathrm{O}$ policies may be triggered by shareholder claims challenging management's response to the pandemic. Reports already exist of insurers reducing D\&O coverage and increasing retentions because of concerns over pandemic-related liability claims (Grzadkowska, 2020, 13 August).

\subsubsection{Errors and Omissions Liability Insurance}

At the end of November 2020, few reports exist of claims being made against agents and brokers for failing to procure appropriate coverage for COVID-19 losses or uncovered liabilities, thereby triggering errors and omissions $(\mathrm{E} \& \mathrm{O})$ coverage purchased by agents and brokers

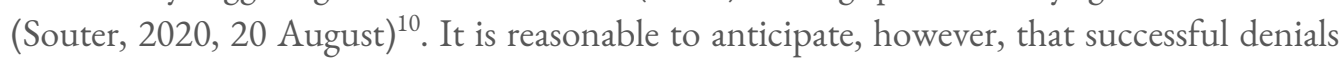
of coverage by insurance companies will cause some policyholders to turn to the agents and

10 Some plaintiffs have reportedly added brokers and agents as named defendants in an attempt to defeat diversity jurisdiction in federal courts and allow the case to be filed in state court. See Timothy G. Ventura (2020, 20 August). 
brokers who helped place the coverage and claim that they failed to procure adequate insurance against the consequences of the pandemic ${ }^{11}$. These claims will face significant hurdles, including the argument that agents and brokers cannot be negligent for failing to procure coverage that is unavailable in the market. Yet considerable evidence exists that the possibility of $\mathrm{E} \& \mathrm{O}$ claims in large numbers is a matter of substantial concern in the industry ${ }^{12}$.

\subsection{Workplace Injury and IIIness Risk; Employers Liability Insurance}

Workers compensation insurance protects employees from illnesses and injuries suffered during the course of employment. These products fulfill statutory schemes that shift employer liability for such illnesses and injuries to first-party compensation mechanisms. Because COVID-19 is transmitted so easily, workers in any industry that requires human interaction for the performance of job duties face substantial risks. Thus, it is foreseeable that many workers will assert that their infections occurred on the job and therefore trigger workers compensation coverage.

Most workers compensation laws and policies exclude "ordinary diseases of life", a term which is generally understood to refer to diseases to which the public is exposed. This exclusion would seem to unambiguously apply to COVID-19, but the analysis is not that simple. If an illness is demonstrated to be a specific hazard of employment, then what is otherwise an "ordinary disease of life" is classified as an occupational disease, and workers compensation insurance applies (Magarick \& Brownlee, 2020, $§ 40: 33$ ). An obvious example is asbestosis; a member of the general public can develop the disease if exposed to asbestos particles, but it is much more common for employees in the asbestos products manufacturing industries to become afflicted.

This suggests alternative possibilities for how workers compensation insurance applies in to COVID-19 infections acquired in the workplace. Before the pandemic, at least 19 states in the U.S. had declared that lung and respiratory illnesses developed by firefighters and other first responders were presumed to be work-related and therefore covered under workers compensation policies (Racicot \& Spidell, 2018, November). The logic of this answer is that these workers are required, as a part of their jobs, to encounter dangerous substances, especially in the air, and thus what might otherwise be considered "ordinary diseases" are no longer "ordinary" when workers are forced into repeated exposures to the agents that cause the diseases. In the COVID-19 pandemic, workers in what were previously not considered hazardous occupations are now required to confront a dangerous pathogen that spreads easily from human to human. Thus, those who are required to work with the virus as a part of their job duties, which clearly includes health care providers, laboratory workers, and first responders, are arguably entitled to workers compensation coverage for coronavirus infection. This is how U.S. federal employees are being assessed for employees' compensation eligibility; proximity to the virus due to job duties in the employment setting is the core factor in the analysis, and federal workers "who have direct and frequent in-person and close proximity interactions with the

11 For a discussion of the theories of recovery available to policyholders who proceed against agents and brokers, see Jerry \& Richmond $(2018, \$ 35[\mathrm{f}])$.

12 See, e.g., Jones (2020, 21 September), Swiss Re Corporate Solutions (2020): summary of best practices for brokers and agents to avoid E\&O exposure due to COVID-19. 
public may be considered to have high-risk employment as it relates to COVID-19”13. At least sixteen states have amended their workers compensation laws by statute or emergency executive order to extend workers compensation coverage to COVID-19 infections incurred by front-line workers, which sometimes include workers in "essential" businesses ${ }^{14}$.

Thus, at the end of November 2020, the extent to which COVID-19 will disrupt the workers compensation insurance sector is uncertain. But the possibility that this impact will be severe cannot be casually disregarded ${ }^{15}$. At the least, it is inevitable that premiums in this sector will significantly increase in 2021.

\subsection{Business Continuity Risk: Event Cancellation}

Event cancellation insurance is often purchased by sponsors of conferences, sporting events, concerts, fairs, festivals, trade shows, and other events to cover the risk of loss of event-related revenue (and the concomitant inability to pay event expenses) due to circumstances beyond a sponsor's control. Hotels and other establishments whose income is driven by the revenue from such events might also purchase event cancellation coverage.

The forms used by insurers in this market have much variability. Many policies are written on an all-risk basis, which extends coverage to any cause unless specifically excluded. Other policies specify covered perils, and communicable diseases, epidemics, or pandemics are occasionally listed among these covered perils. In addition, the triggering language in these policies varies, which may be important depending on whether the event was cancelled, postponed, curtailed, or had reduced attendance. Most event cancellation policies contain an explicit exclusion for cancellations caused by a communicable disease, and the insured that desires this coverage buys back the coverage, if the insurer is willing to sell it, through an extra premium that secures an endorsement that negates the exclusion. Recent reports suggest that most policies sold before mid-March 2020 have these buy-back provisions, but policies sold since then have limited communicable disease coverage and often include full exclusions for viruses generally and COVID-19 specifically (Masters \& Ellis, 2020, 10 August) ${ }^{16}$. As of mid-November

13 FECA Bulletin No. 21-01, Special Case Handling in COVID-19 FECA Claims Processing and Adjudication, 21 Oct. 2020, https://www.dol.gov/agencies/owcp/dfec/regs/compliance/DFECfolio/FECABulletins/FY2020-2024 (accessed 21 Nov. 2020).

14 See Ogletree Deakins, Chart: Orders and Other Authority or Guidance to Provider Workers' Compensation (WC) Coverage for COVID-19, 22 Oct. 2020, https://ogletree.com/app/uploads/covid-19/COVID-19-Workers-Compensation-Coverage.pdf?Version=12 (accessed 21 Nov. 2020) (describing developments in each of the 50 states). See also NCCI, Survey of State Workers Compensation Compensability Statutes (2020), https://www.ncci.com/Articles/Pages/Insights-Compensability-Statutory-Survey-May-2020.pdf (accessed 21 Nov. 2020).

15 For example, the September 2020 Florida Division of Workers' Compensation 2020 COVID-19 Report, which summarizes data as of 31 Aug. 2020, (available at https://www.myfloridacfo.com/Division/WC/PublicationsFormsManualsReports/Reports/2020-COVID-19-September-Report.pdf, accessed 21 Nov. 2020),

16 One prominent U.S. events cancellation insurer states on its website in bold red letters: "Please note that if you are seeking event cancellation coverage pertaining to Coronavirus COVID-19, this is not available as it is deemed a pre-existing condition and it is specifically excluded from all event cancellation policies issued through our program from January 2020 forward”. K\&K Insurance, Home Page, https://www.kandkinsurance.com/EventsAttractions/Pages/Event-Cancellation.aspx (accessed 18 Nov. 2020). 
2020, it appears that communicable disease coverage is not available from any insurer — for any disease, not just COVID-19 $9^{17}$.

The number of events worldwide cancelled due to COVID-19 is enormous ${ }^{18}$, and the extent to which these events are covered under event cancellation policies is unknown. One prominent example of a significant cancellation for which insurance was available is the All-England Lawn Tennis Club's reported receipt of an insurance payout of approximately USD 142 million for the cancellation of the June 29-July 10, $2020 \mathrm{Wimbledon}$ tennis tournament ${ }^{19}$. Event cancellation insurance is often written years in advance of the event (as planning for such events is often years in the making), and it is probable that underwriters did not anticipate in pricing this coverage the scale of the ongoing pandemic. These claims are being processed in late 2020, and it is possible that insurers writing this coverage will face significant challenges paying these claims.

\subsection{Motor Vehicle Risk}

The risks covered by motor vehicle insurance have been inversely impacted by COVID-19. The pandemic greatly reduced the number of miles driven by both commercial and personal policyholders, which led directly to a decline in accidents, property damage, injuries, and fatalities. According to one company's monitored cell phone data, commercial fleets in the U.S. showed a decrease of 17 percent in miles driven as of April, and in Europe almost half of commercial fleets experienced drive time reductions of more than 50 percent (Verizon Connect, 2020, 8 September). In the U.S., total miles traveled on all roads and streets declined by 39.8 percent in April 2020 as compared with April 2019 20 . Although the number of miles driven has steadily increased since April 2020, one study predicts that vehicle miles traveled per year are likely to stabilize at a number between nine and ten percent lower than pre-pandemic levels (Silberg et al., 2020, p. 3). This has led to a decline in the absolute number of accidents, injuries, and fatalities, although there is some recent evidence that the number of fatalities per miles driven has increased, which implies that reckless and negligent driving has increased during the pandemic (Blanco, 2020, 1 October) ${ }^{21}$. The reduction in miles driven, which is an extremely powerful correlator with motor vehicle claims and payments, led many auto insurers to refund premiums or reduce rates charged their customers during the current contract terms (McFadin, 2020, 6 October). Although future uncertainties exist about potential declines in the number of vehicles insured due to COVID-19 and the number of policy lapses likely to occur during the global recession, the pandemic does not appear to have created a claims problem in motor vehicle insurance.

17 See Childress, R. (2020, 1 November), quoting Seth Fleischer, of Aon Affinity.

18 See List of Events affected by the COVID-19 pandemic, Wikipedia, https://en.wikipedia.org/wiki/List_of_events_affected_by_the_COVID-19_pandemic (accessed 18 Nov. 2020).

19 Wimbledon Shows How Pandemic Insurance Could Become Vital for Sports. Other Events, Forbes, 13 Apr. 2020. Available at https://www.insurancejournal.com/news/international/2020/04/13/564598.htm (accessed 18 Nov. 2020).

20 Office of Highway Pol'y Infor. (2020, April). Traffic Volume Trends. Available at https://www.fhwa.dot.gov/ policyinformation/travel_monitoring/20aprtvt/ (accessed 4 Nov. 2020)

21 Discussing reports for 2020 Q2 released by National Highway Traffic Safety Administration. 


\subsection{Property Insurance}

Property insurance is most closely identified with the goal of protecting against the risk of destruction of or damage to property. Thus, it is not surprising that for decades, the insurance industry thought little about the implications of communicable diseases for property insurance. A virus or bacterium does not, in and of itself, cause physical damage to property like that caused by a weather event, fire, or other force of nature or humankind, and thus accounting for it in policy language was not understood to be necessary.

Property insurance, however, is also about loss of use, and after the 2002-2004 SARS pandemic, the industry took note of how a pathogen might trigger loss of use coverage. The language of policy forms changed - from many policyholders' viewpoints, they were changed quietly to exclude coverage- and thus it is not surprising that today business interruption insurance has become the most prominent of all COVID-19-related insurance topics, and the coverage provided by these policies is the most contested. Accordingly, this line of insurance is examined more closely in Part II.

\section{Business Interruption Insurance}

\subsection{The Purposes of Property Insurance: Physical Loss and Loss of Use}

Property insurance covers two distinct kinds of losses. First, it covers physical damage to the intrinsic elements of the insured property. In the personal lines, individuals own (or sometimes have an economic interest short of ownership in) homes, personal belongings, and automobiles, and the risk is that these tangible properties might be destroyed, damaged, or dispossessed (such as, for example, by theft). Various kinds of property insurance policies are sold to individuals for protection against these risks. In the commercial lines, the kinds of property insured by businesses include buildings, improvements (often called "betterments" in buildings leased by the insured), equipment, inventory, and property owned by others but in the insured's possession and for which the insured is liable in the event of destruction, damage, or dispossession. The measures of loss are the same in both the personal and commercial markets. If property is destroyed or lost, the amount of the loss is the value of the asset or the cost of replacing it. If property is damaged, the amount of the loss is the cost of repair.

The second kind of loss covered by property insurance is the inability to use property when it is destroyed, damaged, or dispossessed. Whereas physical damage or loss is associated with intrinsic structures of property and the values placed on those physical elements, loss of use is associated with the "time value of property". Insurance that covers damage to time value is referred to as "time element insurance". Take the personal lines example of homeowners property insurance: When the policyholder's house is damaged to an extent that it cannot be occupied until repairs are finished, the policyholder needs somewhere else to live, which causes the policyholder to incur an additional out-of-pocket cost beyond the cost of repair. The standard homeowners policy has a time element provision which covers the cost of reasonable substitute housing, which reimburses the policyholder for loss of use. Similar provisions exist in automobile insurance, where the first-party property coverage typically contains a provision that pays for the rental of a substitute vehicle while the insured vehicle is being repaired. 
Businesses face a similar problem, except that the consequences of damage to the time value of property can be more substantial than the physical damage to the property itself, which is usually not the situation in the personal lines. When, for example, a building in which a business operates is destroyed, or equipment used in the manufacturing process is damaged and becomes inoperable, or inventory being held for sale is destroyed, the policyholder's business may have to shut down, with consequential loss of revenue while many expenses, such as payroll, continue. Moving a business to another location is not an option in many situations. Equipment may be replaceable, but business operations cannot resume in the meantime, which means that revenue streams cease. In the commercial lines, business interruption insurance is intended to address the risk of cessation in business continuity and the loss of income that ensues when it does.

Business interruption can be caused by damage to the insured's own property, but business interruption can result from many other circumstances, such as loss of utility service, shipping disruptions, or a supplier's inability to provide the policyholder with necessary components or materials. These circumstances can arise from many causes, ranging from employee work stoppages to political unrest to physical damage to suppliers' property essential to providing its goods or services. Niche products can be found in the market for most of these risks, but the most common extension of basic business interruption insurance is coverage for business interruption caused by damage to property of others. This coverage is known as "dependent property coverage" in recognition of the fact that the insured's operations can depend on the continued existence of property owned by others. This coverage is also called "contingent business interruption" insurance to signal that income protected by the coverage is contingent on the continued existence of property owned by others. The main reason this extension does not reach the full range of diverse causes is that the extension is made from a base of insurance on business interruption caused by damage to the insured's own property, which is itself an extension from the insurance on the property itself. The dependent property coverage is much broader, however, in one respect: Business interruption claims tend to arise in a defined geographic area, but contingent business interruption claims can arise out of events that occur anywhere in the world ${ }^{22}$.

Thus, with respect to owned property and property for which a business is legally responsible, businesses face the risk that the property they own or possess might be destroyed, lost, or damaged, thereby creating out-of-pockets costs for replacement or repair, and the further risk that destruction, loss, or damage to this property might cause a suspension of operations that in turn causes a loss of income. When businesses conclude that these risks cannot be managed through prevention, mitigation, or self-insurance, businesses seek, if they can afford it, to insure these risks by purchasing insurance. Most observers believe that most mid-size to large businesses purchase business interruption insurance or have it as a part of their commercial coverage packages (Hoffman, 2020, 10 September ${ }^{23}$, but survey data suggest that only about one-third of small businesses acquire business interruption insurance ${ }^{24}$.

22 A classic example is the 2011 earthquake and tsunami in Japan, which disrupted supply chains all around the world. See, e.g., Donald S. Malecki (2011 March).

23 Qquoting Linda Kornfeld, vice chair for insurance recovery at Blank Rome LLP.

24 See Ins. Infor. Inst., Business Interrupted, 1 May 2017, https://www.iii.org/press-release/business-interrupted-celebrate-small-business-week-by-making-sure-insurance-is-part-of-your-business-plan-says-iii-050117 (ac- 


\subsection{Business Interruption Coverage Products}

\subsubsection{Description of the Products}

In the U.S. commercial property insurance market, one of the most common policy forms is the Businessowners Policy (BOP), which is a multiperil package policy ${ }^{25}$ written by the Insurance Services Office (ISO) for the small business market ${ }^{26}$. Insurers that sell this form have different eligibility requirements for their purchasers, but typical ones involve company size (e.g., eligibility limited to companies with fewer than 100 employees), total revenue (e.g., eligibility limited to companies with less than $\$ 3$ million in annual revenue), and riskiness of the industry (i.e., only firms in low-risk industries are eligible) $)^{27}$. As explained in more detail below, the BOP contains business interruption coverage unless the coverage is specifically removed by endorsement.

Companies not eligible to purchase the BOP (and some small companies with specialized risks that prefer or need customized coverage) typically purchase a Commercial Package Policy (CPP), which is essentially a form that provides basic property and liability coverages, and then is expanded by endorsement to cover other risks for which protection is desired ${ }^{28}$. The functions of this coverage can also be accomplished through the purchase of multiple standalone policies. One of the endorsements to the basic package or one of the stand-alone policies may be business interruption insurance.

Very large companies typically have their own risk management departments that work with brokers and agents to build the customized packages that they need. The packages are more complex, typically having multiple policies that coordinate with the others and with company retentions both horizontally and vertically. Business interruption insurance commonly exists as one of the coverages within these more complex packages.

Insurers use many different forms to provide these various coverages, which means that different coverage language exists across the industry ${ }^{29}$. Yet despite the vastness of the industry,

cessed 22 Nov. 2020) (citing 2015 Nationwide Insurance Company survey; defining small business as one with 50 or fewer employees).

25 Until the 1960s, commercial insurance was sold in the U.S. on a single-line basis. This was largely because of state licensing regulations that restricted agents and brokers to selling in either the property or liability markets, and thus insurers focused on one side of the market or the other. In the 1950s, consumer demand for package policies led to legislative abrogation of the restrictions on multiline marketing, and this trend reached the commercial markets approximately a decade later. For more discussion, see Kimball (1960, pp. 117-19).

26 See ISO, Businessowners Coverage Form (hereafter “BOP”), BP 00030713 (2012).

27 For a discussion of one company's eligibility rules, see D'Orlando (2012), handout at conference sponsored by Union Mutual of Vermont.

28 See Ins. Inf. Inst., Understanding commercial package policies, undated, https://www.iii.org/article/understanding-commercial-package-policies (accessed 22 Nov. 2020)

29 Although many insurers seek to keep their forms inaccessible (except, of course, to policyholders), there are ways to examine the different coverages. First, occasionally a company's form will find its way to being posted on the Internet. Second, in many states, all insurance company filings, including form approvals, are open to public inspection at the website of the state insurance department. Third, the pleadings in cases filed by policyholders against insurers are almost available to public inspection, and increasingly these files are available on the Internet; 
more consistency exists than one might expect due to the influence of the ISO (Bonner, 2019, $16 \mathrm{May}^{30}$. Hundreds of insurance companies subscribe to the services provided by the ISO, which essentially means that they pay the ISO to draft policy forms, collect data on the forms' performance, keep track of litigation involving the forms, and update policy language to respond to court decisions and changing market conditions. Thus, a company that belongs to the ISO is paying for the ISO's expertise in drafting the form, and thus is likely to use it verbatim. If the company modifies the form, the company risks losing the standardization that makes the ISO's data collection on the effectiveness of the form valuable. But if a company decides to change the form for some reason, it is very likely that the revised form will be very similar to the ISO form. Further, companies that write their own proprietary forms are likely to use language very similar to the ISO form. Nevertheless, because differences do exist in the marketplace, it is always important to be alert to these differences and mindful of the possible implications of different language for the scope of coverage in particular cases.

\subsubsection{Product Design and the Problem of Surprise}

As the foregoing description of the property insurance market explains, coverage begins with a base of protection for destruction, damage, or dispossession of property, and then adds various extensions of coverage for other kinds of losses related to that destruction, damage, or dispossession. In other words, the general frame for property insurance - and its extensionsis physical damage to property, i.e., alterations to the intrinsic characteristics of the property itself. When companies draft, market, and sell coverage, it is reasonable to postulate that the companies focus on coverage within the frame, and do not think as carefully about possibilities that might arise outside the frame ${ }^{31}$.

Until 2020, insurers and policyholders did not have significant shared experiences with pandemics. Relative to other kinds of perils, epidemics and pandemics are relatively infrequent; the last catastrophic pandemic was over 100 years ago, and twenty-first century policymakers and decisionmakers had not placed this risk in the highest category of concerns requiring a mobilization of thought and resources. This suggests the possibility that the insurance industry underestimated the risk of a catastrophic pandemic, and, in doing so, did not give the highest degree of care to considering how policy language drafted in a physical damage frame could be alleged to apply — and would be applied — to pandemic-caused losses. Influenced by the physical damage frame, it may be that the industry, bolstered by an assumption that the physical property trigger requirement was tightly constructed, underinvested in efforts to create clear policy language for pandemics. As one commentary states, " $[\mathrm{t}]$ heoretically, the industry's [...] economic losses should be low given the fact, for the most part, they did not

the insurance policy at issue will usually be attached to one of the pleadings in the case. Recent business interruption coverage litigation, see text accompanying infra, is making many of these forms available to the public.

30 Explaining the history of and services provided by the ISO.

31 Cognitive psychologists have demonstrated that the availability heuristic - a mental shortcut which ties the likelihood of any given event to the ease with which its occurrence can be brought to mind - is a key factor determining judgment and perception. See Tversky \& Kahneman (1982), describing the availability hueristic. How a question or issue is presented - i.e., framed - can affect the decisionmakers' perception of the problem and ultimately the decision itself. See, e.g., Tversky \& Kahneman (1981), explaining framing effects. 
underwrite 'pandemic' disruption. However, the degree to which coverage may have been unwittingly provided is going to be severely tested" 32 .

Because, as noted earlier, many different business interruption forms are used, any generalizations about coverage must be made cautiously (French, 2020, outlining and summarizing the general arguments). Precise assertions about whether, and the extent to which, a possible mismatch exists between insurers' intent not to cover pandemic-caused disruptions to business and the coverage actually provided to policyholders requires detailed analysis of policy text, and the results of any such inquiry cannot be applied beyond the form being studied. Yet because commonly used forms have a common core of similar text, painstaking analysis of one commonly used form can aid in the understanding of insurers' intentions, policyholders' expectations, and the contours of the disagreements insurers and policyholders will have about the scope of coverage.

The exploration in the next subsection will use the BOP as the reference point for this inquiry. This discussion will show a lack of textual precision at multiple points in the triggering language in the BOP form relevant to business interruption coverage (e.g., the meanings of "suspension of operations", "direct physical loss or damage", "prohibits access", and the "immediately surrounding" language in the civil authority coverage), which suggests that insurers, influenced by the BOP's physical damage frame, underinvested in efforts to draft clear time element coverages with respect to the risk of pandemics. But some insurers, in the aftermath of the 2002-2004 SARS pandemic, inserted a virus exclusion in their policies, thereby demonstrating responsiveness to cues of a changing risk environment, consideration of the implications of these cues, and recognition of the need to adjust policy coverage in response to these warnings.

\subsection{The ISO’s Businessowners Policy: Overview}

The BOP is divided into three sections: Section I is the property coverage, Section II is the liability coverage, and Section III is a set of conditions applicable to both Sections I and II. Both Section I and II have sections with definitions relevant to each of those sections. Business interruption coverage is found in Section I, but only after the basic coverage for physical loss is created in the Section I-A insuring agreement. The Section I-A insuring agreement states as follows:

We will pay for direct physical loss of or damage to Covered Property at the premises described in the Declarations caused by or resulting from any Covered Cause of Loss.

This language sets forth the insurer's duty in the event property covered under the terms of the policy is destroyed, damaged, or lost through dispossession.

The subsections within Section I-A provide more detailed meaning for the insurer's duty set forth in the Section I-A insuring agreement. Section I-A-1 describes what specific kinds of property are covered, and Section I-A-2 describes some specific kinds of property that are not

32 Autonomous, Insurance: Scaling the industry non-life loss, Research Rpt., 26 Apr. 2020, quoted in Richter \& Wilson (2020, p. 191). 
covered. Section I-A-4 contains a set of limitations describing circumstances in which damage to or loss of covered property is not covered ${ }^{33}$.

Section I-A-3 sets forth what constitutes a "covered cause of loss". The default BOP form is an “all-risk" policy. This results from this Section's description of covered causes of loss as “Direct physical loss unless the loss is excluded under Section I-Property”. Thus, any "direct physical loss" - regardless of how the loss is caused - is covered by the policy unless that loss is subject to a separate limitation or exclusion. The policyholder's burden is simply to prove that a loss occurred. In "specified risk" BOP policies, this broad language in I-A-3 is replaced, usually by endorsement, with a specified list of perils (such as, for example, fire, lightning, windstorm, hail, vandalism, sprinkler leaks, etc.). Under this version of the policy, the policyholder carries the burden to establish not only that a loss occurred but also that the loss was caused by one of the specified perils.

Section I-A-5 is titled "Additional Coverages", and it is here where the BOP addresses the subject of time element coverage. Section I-A-5 contains eighteen different coverages which are not, in and of themselves, direct physical damage to the described premises in Section IA-1. Rather, these additional coverages refer either to collateral damage or losses when physical damage occurs (such as, for example, the cost of debris removal, fire department service charges, etc.), costs incurred to protect covered property from a covered loss (thereby mitigating the amount that an insurer would otherwise have to pay for a larger loss), or other categories of coverage that the insurer inserts into the multiperil form (such as, for example, losses caused by forgery or alteration or by accepting counterfeit money or money orders; the cost of replacing or restoring electronic data that has been destroyed or corrupted; etc.). "Business income" is the sixth in the list of additional coverages (Section I-A-5-f), and this is the coverage provision that is commonly understood as the business interruption protection provision.

Each of these "Additional Coverages" has its own distinct insuring agreement, apart from the general insuring agreement in Section I-A. Thus, the "direct physical loss of or damage to" language in Section I-A does not limit, in and of itself, the coverages provided in I-A-5's various paragraphs. However, when this language is repeated in one of the paragraphs, standard principles of interpretation point toward interpreting the language to mean the same thing in each location.

Three paragraphs in the "Additional Coverages" set the framework for business interruption coverage. First, paragraph (f) in Section I-A-5 contains the basic business interruption coverage language, and this paragraph uses the same "direct physical loss or damage" language found in the general insuring agreement in Section I-A. Second, paragraph (i) in Section I-A-5 is titled "Civil Authority". In one sense, this coverage is an extension of the business income provision in I-A-5-f, in that I-A-5-i expands the business interruption protection in I-A-5-f beyond the situations covered there. But in another sense, the paragraph (i) language is organizationally parallel to the general business interruption provision in paragraph ( $\mathrm{f}$ ), and thus should be read as an independent additional coverage with its own triggering language. Third,

33 To elaborate, Section I-A-2 describes kinds of property that are not covered, whereas Section I-A-4 pertains to certain kinds of property that are generally covered but are not covered under certain circumstances. For example, steam boilers, turbines, and pipes are covered parts of a building within the language of Section I-A-1, and are not taken outside of coverage by Section I-A-2; but Section I-A-4 explains that if the damage to those elements occurs on account of defect within the element, the policy does not provide coverage. 
paragraph (m) in Section I-A-5 is titled "Business Income from Dependent Properties". This paragraph contains what is commonly known as the contingent business interruption insurance coverage. Like the civil authority coverage, the contingent coverage appears as an extension of the general business interruption coverage in I-A-5-f, but in the organization of the policy, this paragraph can also be understood as an independent, additional coverage with its own triggering language.

After the coverage grants in section I-A, Section I-B sets forth exclusions from the coverage grants. The section begins with prefatory language, known as the "anti-concurrent causation provision", which essentially provides that if any of the exclusions that follow contributes to the loss or damage, either directly or indirectly, in any sequence, or in any concurrent manner, the entire loss is excluded from the coverage otherwise provided in Section I-A.

A list of exclusions follows this prefatory language. Among the exclusions listed in Section IB is paragraph ( $\mathrm{j})$, which is titled "Virus Or Bacteria". It applies, by its terms, to "[a]ny virus, bacterium or other microorganism that induces or is capable of inducing physical distress, illness or disease". As is evident from this exclusion's title, this exclusion has significant implications for the coverage of the BOP for any kind of loss, including business interruptions, caused by COVID-19.

Thus, there are three provisions in the ISO BOP that have critical importance for business interruption claims during the COVID-19 pandemic: the "Business Income" coverage language in Section I-A-5-f; the "Civil Authority" coverage language in Section I-A-5-i; and the "Virus Or Bacteria" exclusionary language in Section I-B-j. This article's next section explores each of these provisions in more detail.

\title{
2.4. Detailed Analysis of Three Key Provisions in the ISO's BOP
}

\subsubsection{The General Business Interruption Trigger in Section I-A-5-f}

The paragraph (f) "Business Income” coverage in Section I-A-5 states:

\begin{abstract}
We will pay for the actual loss of Business Income you sustain due to the necessary suspension of your "operations" during the "period of restoration". The suspension must be caused by direct physical loss of or damage to property at the described premises. The loss or damage must be caused by or result from a Covered Cause of Loss [...] We will pay only for loss of Business Income that you sustain during the "period of restoration" and that occurs within 12 consecutive months after the date of direct physical loss or damage $[\ldots]$
\end{abstract}

For the insured to be entitled to coverage under this triggering language, the insured must prove six different elements.

First, there must be "actual loss of Business Income". Proving the amount of monetary loss properly attributable to a business interruption has numerous complexities (French, 2014), but none of these is unique to business interruptions caused by COVID-19.

Second, the loss of business income must be due to a "necessary suspension of operations". The term "suspension" is not defined in the BOP. As used in paragraph (f), most courts have 
held that "suspension" is bimodal: either business operations are suspended, or they are not. It follows from the bimodal interpretation that a suspension does not occur when the business is only partially disrupted and is therefore operating (i.e., a business cannot be suspended when it is operating, and a business can be suspended only if its operation ceases $)^{34}$. This draws support from the plural use "operations", which suggests that if one operation is still functioning, the plural-operations requirement has not been met $^{35}$. In the pandemic, many businesses have suffered total suspensions of all operations, but there are many others that have continued to operate on reduced schedules, as when, for example, the business stays open but with caps on the number of customers allowed in the premises, or the restaurant maintains carry-out operations while inside-dining is closed. Insurers will argue, and should expect success in many cases, that doing business under difficult conditions, or suffering a reduction in business activity, is not the same as a suspension of operations.

Some policies use different language with respect to this element, and the results in these cases may be different. For example, if a policy covers income loss due to "necessary or potential suspension" of the insured's operations, it may be that a business that scales down its business operation in the face of a threatened suspension will fall within the terms of this coverage ${ }^{36}$. Policies that define "suspension" as a cessation or slowdown are very likely to produce different answers. Given the weight of authority requiring complete cessation to establish a suspension, it may be that if a policy requires a "necessary interruption" as opposed to a "necessary suspension”, a court may agree with a policyholder's argument that the insurer used a different word because it did not intend to require a complete cessation, and thus conclude that a partial reduction in business causing some loss of income is covered ${ }^{37}$.

Third, the loss of income for which the insurer will pay is what is demonstrated to have occurred during the "period of restoration". This term is defined in the policy ${ }^{38}$, and it refers to the time that is required to replace or rebuild the property that was damaged, destroyed, or dispossessed. The period is a theoretical measure, in that an insured who takes longer than reasonably necessary to rebuild cannot recover for the entire period of delay. The current BOP limits the period of restoration to twelve months, but the period might be longer in standalone or customized policies.

34 See, e.g., Buxbaum v. Aetna Life \& Cas. Co., 126 Cal.Rptr.2d 682 (Cal.App.2d Dist. 2002) (where leak in water pipe slowed law firm's business but did not cause a total cessation, business interruption policy provided no coverage); Royal Indem. Ins. Co. v. Mikob Properties, Inc., 940 F. Supp. 155, 160 (S.D. Tex. 1996) (where a fire in a portion of an apartment complex caused loss of rental income, no coverage existed because the entire complex did not experience a suspension in operations).

35 The BOP defines the term "operations" as “your business activities occurring at the described premises". BOP, Section I-H-8.

36 See, e.g., American Medical Imaging Corp. v. St. Paul Fire \& Mar. Ins. Co., 949 F.2d 690 (3d Cir. 1991) (where policy required "necessary or potential suspension", insured was allowed to present to a jury a business interruption claim where it was required to move its operations to a location with less capacity).

37 See, e.g., Archer Daniels Midland Co. v. Aon Risk Services, Inc. of Minn., 2002 WL 31185884 (D. Minn. 2002), judgment aff'd, 356 F.3d 850 (8th Cir. 2004).

38 See BOP, Section I-H-9. 
Fourth, the suspension must occur at "the described premises", which means that the business activities that are interrupted must occur at the premises insured by the policy, meaning the premises described in the policy's declarations.

Fifth, the suspension must be caused by a "Covered Cause of Loss". This refers to the coverage described in Section I-A-3, which, as discussed above, will either be "all-risk" coverage or "specified-risk" coverage.

The sixth element is, in the context of COVID-19, has engendered the most controversy. This element requires the insured to prove that the suspension was "caused by direct physical loss or damage to property" at the premises described in the policy. This language links the business interruption coverage back to the insuring agreement in Section I-A, where identical language appears. Because Section I-A is addressing the structural, physical alteration of property, insurers argue that the business interruption coverage in Section I-A-5-f requires that the business interruption be caused by the same kind of structural, physical damage described in Section I-A. The essence of the insurer's argument is that all the coverages in the separate paragraphs in Section I-A-5 extend from, and are in addition to, the basic coverage in the Section I-A insuring agreement. These additional coverages have their own triggering language, but when an additional coverage uses the same triggering language as Section I-A, that additional coverage's triggering language should be understood in the same sense as that language appears in Section I-A.

In the pandemic business interruption cases, the COVID-19 virus does not appear to cause the kind of property damage addressed by the triggering language in Section I-A. Thus, it is argued, COVID-19 does not cause the direct, physical consequence that is a prerequisite to business income recovery under paragraph (f). The virus is in the air, and it does not damage property while it is "in the air"; the virus lands on surfaces, but it does not cause damage to these surfaces. Even if an expert were to opine that when the virus lands on a surface it causes microscopic etching on such surfaces (and hence "damage" to such surfaces), it does not necessarily follow that damage invisible to the naked eye which does not impair the functionality of contaminated surfaces constitutes physical damage within the meaning of the policy. A virus can be eradicated with disinfectant ${ }^{39}$ and this is a process that can be completed in a matter of minutes or hours ${ }^{40}$; thus, it follows, by this analysis, that no damage occurs. Furthermore, the virus has a rate of decay beyond which it does not survive; thus, if a facility which has COVID-19 contamination is locked up for some period of time and human occupation of the facility is prohibited, the virus will die without causing any physical injury or damage to the property ${ }^{41}$. In other words, this sixth element, by its terms requires that prop-

39 Disinfectants, by design, kill living organisms. "Coronavirus is an RNA enveloped virus and generally not highly resistant to disinfectants and can also be inactivated by heat and ultraviolet irradiation” (Takagi \& Yagishita, 2020, 18 July).

40 See CDC, Cleaning and Disinfection for Community Facilities: Interim Recommendations for U.S. Community Facilities with Suspected/Confirmed Coronavirus Disease 2019 (COVID-19), 10 Sept. 2020, https:// www.cdc.gov/coronavirus/2019-ncov/community/organizations/cleaning-disinfection.html (accessed 22 Nov. 2020) (describing best cleaning and disinfectant practices for rooms contaminated with COVID-19 virus).

41 The rate of decay of the virus on different surfaces is a matter of intensive scientific study, and the results are still uncertain. See, e.g., Riddel, Goldie, Hill, Eagles, \& Drew (2020, 7 October), finding that viable virus can exist for up to 28 days on some common surfaces under some conditions, a longer period than generally considered 
erty be altered in appearance, shape, color, or some other material dimension ${ }^{42}$, and this does not happen with COVID-19.

Policyholders, however, contest this understanding of this sixth element with arguments that the language is ambiguous. When language is ambiguous, it is construed against the drafter under the doctrine of contra proferentum, and the insured's interpretation, if it is reasonable, should be used. From the policyholders' perspective, the triggering language in Section I-A is applies only to the matters addressed in that section, and the additional coverages in Section I-A-5 are add-ons with independent triggers that must be interpreted within the context of those specific coverages, unaffected by the language in Section I-A.

First, policyholders argue that the words "loss of" and the words "damage to" are separated by "or", which indicates that loss and damage have different meanings; otherwise, the drafters would not have needed to use, and would not have used, both words. If "damage to" refers to impacts that produce physical alterations, then "loss of" may refer to loss of use or function, inaccessibility, unavailability for use, or dispossession. The basic point is that a property owner can suffer the physical loss of property through theft or dispossession, without the occurrence of any actual physical damage to the property. The adjectives "direct" and "physical" do not prevent attributing this meaning to "loss" because the unavailability of something for use may occur "directly" and is "physical" when physical presence or access is lost. Insurers will counter that "loss" has a distinct meaning, in that it refers to dispossession which must be direct and physical, as is the case with theft. Under this reasoning asserted on behalf of the insurer, property contaminated with COVID-19 is neither stolen nor dispossessed; there being no physical damage, the business interruption coverage is not triggered.

Insureds will also point to cases where gases, vapors, odors, ash, or smoke were deemed to be physical damage to property ${ }^{43}$. The argument successfully made in those cases was that while the odors, gases, or smoke did not physically alter the property, the business interruption loss was still covered. The basic point made in these cases is that when an intrusion renders a building unusable or uninhabitable, a physical loss of property has occurred, even if the building itself is unharmed. A virus arguably shares common characteristics with an odor or a gas, and the damage is similar; indeed, viruses, gases, odors, smoke, etc. are physical in nature. Insurers will respond that in these cases, the gases, odors, or smoke were so deeply embedded in the property that the property could not be easily fixed and made ready for the resumption of business activity. A virus that can be easily cleaned and eradicated does not fit neatly within the scope of the precedents where gases, etc. required substantial cleanup expenditures, but some courts might conclude that the probability of reinfection of the premises whenever human occupancy resumes is enough to pull the COVID-19 situation within the scope of these precedents.

possible under earlier studies. However, there is no doubt that the virus has finite survivability, which is probably measured in terms of hours, days, or weeks depending on the circumstances.

42 For discussion of the case law on this point, see DiMugno (2020, June); DiMugno (2020, 6 November); LiMandri et al. (2020, 19 June).

43 See id. (cases discussed in cited sources). 


\subsubsection{Section I-A-5-i Civil Authority Coverage}

The Civil Authority provision in Section I-A-5-i covers business interruption caused by different circumstances than the basic business interruption coverage in in paragraph (f). The current BOP civil authority triggering language states:

When a Covered Cause of Loss causes damage to property other than property at the described premises, we will pay for the actual loss of Business Income you sustain and necessary Extra Expense caused by action of civil authority that prohibits access to the described premises, provided that both of the following apply:

(1) Access to the area immediately surrounding the damaged property is prohibited by civil authority as a result of the damage, and the described premises are within that area but are not more than one mile from the damaged property; and

(2) The action of civil authority is taken in response to dangerous physical conditions resulting from the damage or continuation of the Covered Cause of Loss that caused the damage, or the action is taken to enable a civil authority to have unimpeded access to the damaged property.

Civil Authority Coverage for Business Income will begin 72 hours after the time of the first action of civil authority that prohibits access to the described premises and will apply for a period of up to four consecutive weeks from the date on which such coverage began $[\ldots]$

To satisfy this trigger, the policyholder must satisfy four elements. First, a "Covered Cause of Loss" must cause the loss, as is the case with the triggers previously discussed. Second, there must be "actual loss of Business Income", which is identical to the language in the paragraph (f) business income trigger.

Third, the covered cause must cause "damage to property other than property at the described premises". This language makes clear that damage to the insured's own property is not necessary as a prerequisite to Civil Authority coverage, but there must be damage to property, whether or not owned by the insured, not at the described premises. Significantly, the words "direct" and "physical" do not appear in this formulation, and the word "loss" is omitted as well; this suggests that the damage to property triggering this coverage may be broader than what is contemplated in paragraph (f), although, as discussed in the next element, this supposed additional breadth might be undercut by language in subparagraph (2).

Fourth, the loss must be caused "by action of civil authority that prohibits access to the described premises". In the current COVID-19 context in the U.S., "civil authority" refers to a state or local government agent who has issued COVID-19 orders, but a federal order would fall within this element also. "Prohibits access" is not a defined term in the policy. This phrase might be construed to mean "prohibits all access", under the logic that if some access is allowed, then access is not prohibited. Analogizing to the suspension of operations element which appears in paragraph (f), an insurer would argue that if access is only hindered or made more difficult, it has not been prohibited. A different reading, however, only the prohibition of some access is necessary to meet the element, as a prohibition of some access is a prohibition of access. What hangs in the balance in the interpretation of this phrase is whether meeting this element requires COVID-19 governmental orders to shut down business operations in their entirety, or whether it is sufficient that the orders allow business to continue but with 
restrictions (as, for example, in number of customers or hours). The text is clear, however, that whatever the order's scope, it must be mandatory; voluntary cessations of business do not satisfy this element.

This fourth element is subject to two qualifications, both of which must be met, with the second of the two needing to be met in only one of two ways. First, the government order must prohibit access to the "area immediately surrounding the damaged property", and the insured premises must be no more than one mile from that property. This suggests that the area of prohibited access is both adjacent and bounded; an order which is geographically unrestricted arguably does not meet this standard. Yet it could be maintained that the area in which access is prohibited must be adjacent to damaged property, which is inevitably true when a blanket government shutdown order is issued. Second, the order must be a response to "dangerous physical conditions" resulting from either the damage or the continuation of the covered cause that produced the damage, or, alternatively, the order's purpose must be to enable the civil authority "to have unimpeded access to the damaged property". This second prong implies that the damaged property must be physically damaged in its intrinsic elements, thereby raising all of the issues discussed with respect to the business income coverage in paragraph (f). In the COVID-19 context, the unimpeded access prong is irrelevant.

An earlier version of the BOP required the government orders to be due to "direct, physical loss of or damage to property" other than the described premises -language identical to the language in paragraph (f) and which raised all of the issues discussed earlier. This earlier language, which is most likely present in some policies currently in force, suggested more directly that the Civil Authority coverage was triggered in situations where an event in the vicinity of the insured's property caused direct, physical damage to property not owned by the insured, and this event caused a government authority to take action prohibiting the insured's access to the insured's own property. The fact that the current BOP changed this prior language will permit the argument that broader coverage is intended by the new form, particularly with respect to the removal of language requiring direct, physical damage to the property of others.

One additional important feature of the Civil Authority coverage is that it contains a sublimit on the amount of coverage provided. If the coverage is triggered, the provision has two internal coverage limits: there is a 72-hour waiting period before the coverage goes into effect, and once effective, the coverage only lasts for four weeks ${ }^{44}$.

\subsubsection{The Section I-B-j Virus Exclusion}

After the 2002-2004 SARS pandemic, the insurance industry became concerned that the forms in use did not have language clearly excluding losses caused by viruses, bacteria, and other pathogens. Damage to physical structures was not something expected from a virus or bacterium, but the potential of virus- or bacteria-induced epidemic or pandemic conditions to cause losses covered by time element coverages became an object of substantial industry concern. The ISO undertook to draft a broad exclusion, and it submitted this exclusion, titled "Exclusion of Loss Due to Virus or Bacteria”, CP 014007 06, to insurance regulators for ap-

44 Under the pre-2012 language, the coverage lasted for three weeks. 
proval in July $2006^{45}$. These approvals were obtained, and an endorsement for attachment to commercial property forms was immediately put into widespread use. In the 2012 revisions to the BOP, this language appeared as an exclusion in Section I-B-j, and read as follows:

\section{B. Exclusions}

1. We will not pay for loss or damage caused directly or indirectly by any of the following. Such loss or damage is excluded regardless of any other cause or event that contributes concurrently or in any sequence to the loss. These exclusions apply whether or not the loss event results in widespread damage or affects a substantial area.

$* * *$

j. Virus Or Bacteria

(1) Any virus, bacterium or other microorganism that induces or is capable of inducing physical distress, illness or disease [...]

COVID-19 is a virus, and thus this exclusion by its plain language appears to shut down the path to coverage. A "communicable disease" exclusion is arguably different; a virus is simply a packet of nucleic acid that, when outside a living cell, is simply a dormant particle. As such, viruses are not diseases themselves, but are microorganisms that cause disease (Drexler, 2010). Depending on how a communicable disease exclusion is worded, that kind of exclusion might have different implications in the context of COVID-19. More important, however, is the fact that some proprietary commercial property insurance forms do not contain any kind of virus exclusion. Results in these cases will turn on how the trigger language in the additional coverages is construed.

The paths to attack the paragraph (j) exclusion are limited. Policyholders can be expected to argue, as some did when the pollution exclusion was introduced in commercial liability insurance many years ago, that the industry misrepresented the scope of the exclusion when it was submitted to regulators for approval. This argument is known as "regulatory estoppel", with the upshot being that insurers are estopped to assert the exclusion because of their misrepresentations during the approval process (Lewis, Ellison, \& Debevec, 2020, 7 April, outlining the regulatory estoppel argument). Another anticipated argument will draw upon the law in some states that restricts insurers' use of the anti-concurrent causation prefatory language in Section I-B. Under this line of argument, if a specific exclusion is not the dominant cause in a chain or net of causation, and the dominant cause is covered, the exclusion does not function to remove coverage (Krekstein \& McGowan, 2014, February). Whether the regulatory estoppel and the concurrent causation arguments have force will depend on the case law in particular states.

45 ISO, New Endorsements Filed to Address Exclusion of Loss Due to Virus or Bacteria, 6 July 2006, https://www.propertyinsurancecoveragelaw.com/wp-includes/ms-files.php?file=2020/03/ISO-Circular-LI-CF-2006-175-Virus.pdf (accessed 23 Nov. 2020). 


\subsection{Responses to Insurers' Denials of Coverage during the COVID-19 Pandemic}

The $\mathrm{BOP}$ form discussed in detail above is representative of other business interruption forms used in the marketplace. Differences among these forms are important, but with many aspects of the language of these forms pointing against coverage, insurers have routinely denied coverage when policyholders began to file business interruption claims in connection with COVID-19 shutdowns. Many policyholders have aggressively contested denials of coverage as a final, desperate act to save one's business from extinction ${ }^{46}$. For some of these insureds and for others less desperate, filing a claim is the expression of the policyholders' subjective expectation that a pandemic-induced business interruption is covered by a business interruption insurance policy ${ }^{47}$. As has been demonstrated in recent months, the policyholder pushback to insurers' denials of coverage has been strong.

\subsubsection{Legislative Reform Efforts}

Soon after the initial claim denials occurred, insureds and their advocates sought relief in state legislatures. In March, April, and May 2020, approximately twenty bills were filed in at least seven states ${ }^{48}$ seeking to retroactively mandate coverage. These bills varied in the details, but typical provisions included declaring the virus exclusion void as against public policy or declaring as a matter of law that COVID-19 constitutes direct physical loss or damage to property. Most of the proposals applied to small businesses, which were defined as having fewer than a range of 50 to 250 employees - typically the same businesses that purchase the BOP or equivalent form. Most bills proposed reimbursing insurers for proceeds they paid out of a common fund created by industry-wide assessments or through a promise to use future federal stimulus funds allocated to the state to reimburse the insurers. Other proposals were introduced in the Congress; these proposals also called on the federal government to reimburse the insurers who made payments.

Industry lobbying against these bills was intense, and none was enacted. As of November 2020, it seems clear that none will be enacted. Although the concept of compelling retroactive coverage contrary to policy terms is radical ${ }^{49}$ and probably has federal constitutional problems $s^{50}$, most of these proposals should be understood as efforts to use insurance companies

46 See, e.g., Church \& Hill (2020, 11 September), reporting co-CEO Raymond Gindi commenting on Century 21 bankruptcy that "had we received any meaningful portion of the insurance proceeds, we would have been able to save thousands of jobs and weather the storm".

47 See, e.g., Walsh (2020, 5 August), quoting Nick Gavrilides, restaurant owner in Lansing, Michigan, "I think business interruption claims should be paid when business is interrupted"); Dayen (2020, 11 September): "Many small-business owners expected insurance to help them during the pandemic. They got a rude awakening".

48 Westlaw search, 22 Oct. 2020 (showing bills in New York, Mississippi, Michigan, Rhode Island, Pennsylvania, Illinois, Louisiana).

49 See, e.g., Moorcraft (2020, 15 June), "suggestion of retroactive measures has caused major concern in the industry”; quoting Chubb CEO Evan Greenberg suggesting that it would "bankrupt the industry”.

50 See Modzelewski (2020, 27 August), discussing challenges to retroactive coverage legislation under contracts, takings, and due process clauses of U.S. Constitution. 
as a conduit to quickly get recovery funds from the federal government into the hands of businesses - something that insurance companies are well equipped to facilitate with existing payment structures, and probably able to do so more quickly than hastily constructed federal mechanisms. This aspect of the proposals did not, however, receive widespread discussion. Had these proposals gained traction, at some point businesses without business interruption insurance would have objected on the grounds that they should not have lower priority in the distribution of federal funds than businesses who purchased business interruption policies without coverage for pandemic-induced losses.

\subsubsection{Litigation in the Courts}

The first policyholder lawsuit against an insurer for refusing to pay proceeds under a business interruption policy was filed in Louisiana on March 16, 2020 (Masters \& Levin, 2020, 18 March $)^{51}$. From the end of April through the end of July, between 55 and 80 cases were filed weekly $^{52}$. In response to insurers' denial of business interruption claims, many insureds have also made claims in court. As of 21 December 2020, over 1,400 cases have been filed under business interruption policies in U.S. state and federal courts ${ }^{53}$. Motions to dismiss have been filed by insurers in at least a fourth of these cases ${ }^{54}$, and as of the beginning of 2021, rulings are being issued in a steady stream. As of 22 January 2021, insurers' motions to dismiss or for summary judgment have been granted in 131 cases and denied in 32 cases (i.e., insurers have won approximately 80 percent of the cases). The presence of a virus exclusion in the policy appears to be significant; insurers have won their motions in just over 85 percent of the cases where the policy has a virus exclusion (97 out of 112), but only about 67 percent of the cases where the policy has no such exclusion (34 out of 51$)^{55}$.

The number of cases decided as of early 2021 is small; thus, one must be cautious in drawing conclusions at this early stage in the litigation process. Just over three-fourths (97/124) of the granting of motions to dismiss have been with prejudice, so these cases reflect final judgments for insurers. Dismissals without prejudice might be refiled; some of these may have "corrected" pleadings that are sufficient to survive motions to dismiss. Where motions to dismiss have been denied, many of these cases may simply reflect courts opining that taking all of the allegations of the complaint as true, as courts must do on motions to dismiss, that the plaintiff has pleaded a claim on which relief could be granted. It is reasonable to predict that insurers will

51 Referring to Cajun Conti, LLC, et al., v. Certain Underwriters at Lloyd's of London, et al.). Ironically, Cajun Cont $i$ is the first business interruption COVID-19 case where the insured survived motions to dismiss and summary judgment motions, and is scheduled for trial. See Sams (2020, 12 November).

52 See Penn Law, Covid Coverage Litigation Tracker, https://cclt.law.upenn.edu/ (accessed 26 Jan. 2021).

53 Id. (reporting 1,440 cumulative total filings as of the end of the week of 12 Dec. 2020).

54 An earlier version of the Tracker, see id., listed the number of cases in which such motions had been filed. On 9 Oct. 2020 when the site stated that 1,317 total cases had been filed as of the end of the week of 5 Oct. 2020, the site stated such motions were filed in a total of 325 such cases. This number will grow somewhat.

55 Id. It is possible that these numbers understate insurers' success in defending the COVID-19 business interruption cases. As of 2 Dec. 2020, it appeared that 137 of the cases filed had been voluntarily dropped by plaintiffs, usually before a response to a motion to dismiss was due. See Baker (2020, 2 December). 
win some number of these cases on summary judgment motions and, where those motions are denied, trial on the merits ${ }^{56}$.

\section{Conclusions. Imagining the Future: Managing Business Continuity Risk}

When a disaster happens, it is nearly certain that someone imagined the possibility before it occurred ${ }^{57}$. This is certainly true of the pandemic risk. The significance of the 1918-1919 pandemic (H1N1 virus) ${ }^{58}$ for the business of insurance was discussed as it unfolded (Furbell, 1919, pp. 302-311), and countless analyses of pandemics' ramifications for insurance impacts have occurred since ${ }^{59}$. Yet it was apparently not until the 2002-2004 SARS epidemic that the insurance industry began to alter coverage based on the pandemic risk; shortly after SARS, some insurers inserted exclusion clauses for communicable diseases and epidemics/pandemics into most of their non-life products (Hay, 2020) ${ }^{60}$. The evidence is strong, however, that many insurers underestimated the risk of a severe global pandemic and did not invest adequate resources in achieving policy clarity. Whatever may be said about the adequacy of policy language to effectuate insurers' intent not to cover losses caused by pandemics in some product lines, it is clear that the insurance industry, as a whole, does not intend to cover pandemic-caused business interruption losses on a going-forward basis. This is because the risk pandemics pose to business continuity falls into not only the category of "difficult risk" but also the more extreme subcategory of "systemic risk".

56 In U.S. courts, interpretation of contract language is typically a question of law for the court to decide; thus, in cases where there is no material dispute about an issue of fact, one should expect dispositions of many of these cases in summary judgments.

57 For example, the prospect of a hurricane flooding New Orleans with catastrophic results was known before Hurricane Katrina in 2005. See, e.g., Fischetti (2001, October): “A major hurricane could swamp New Orleans under 20 feet of water, killing thousands [...] [N] ow only massive reengineering of southeastern Louisiana can save the city". The prospect of a terrorist attack on significant U.S. assets by jet airliner was contemplated before 9/11/2001. See, e.g., Clancy (1995), fiction novel in which a pilot flies a Boeing 747 jetliner into the U.S. Capitol dome during a joint session of Congress.

58 The common reference to this pandemic is the "Spanish flu", but this label is incorrect. The origin of the 1918-1919 pandemic is unclear, but a consensus exists that it did not originate in Spain. See, e.g., Trilla, Trilla \& Daer (2008): "Nearly 90 years later [...] virologists and epidemiologists worldwide agree that the influenza virus did not originate in Spain". Many analysts believe the most likely place where the virus began is the United States (specifically, Haskell County, Kansas). See, e.g., Barry (2004).

59 See, e.g., van Broekhoven \& Hellman (2006, May); Dorratoltaj \& Fullam (2018, 29 March); Board on Global Health, Inst. of Med., Nat'l Academies of Sciences, “Adapting Insurance Products for Pandemic Risk”, in Global Health Risk Framework: Pandemic Financing (6 May 2016), https:/www.ncbi.nlm.nih.gov/books/ NBK367975/ (accessed 25 Nov. 2020).

60 The virus exclusion in ISO commercial property insurance was drafted and approved by state regulators after the 2002-2004 SARS epidemic. 


\subsection{Characteristics of Difficult Risks and Systemic Risks}

In the ordinary day-to-day operation of the insurance business, insurers receive the transfers of many kinds and quantities of risks, and then efficiently distribute those risks in pools they manage, occasionally with the assistance of reinsurance or other risk distribution instruments. But some risks are so vast that they challenge the ability of insurance markets to distribute them in reliable insurance pools. These risks are appropriately described as difficult risks.

Difficult risks have essentially two defining characteristics. First, difficult risks resist diversification. The fundamental premise of an effective insurance market is the ability to diversify risk through the power of the law of large numbers. But the law of large numbers works only if the risks being pooled are independent of each other. When this assumption does not hold, as in the situation where every member of a large population is likely to be affected adversely by a peril simultaneously, diversification is at least difficult and may be impossible.

Second, difficult risks are ambiguous in terms of frequency, consequence, or both. When uncertainty exists about the number of events that may happen in a time interval, it is difficult, and perhaps impossible, to calculate how much premium needs to be collected to cover losses. Similarly, when the severity of the consequences likely to arise is uncertain, it is difficult to calculate needed premium. In other words, these ambiguities make it impossible to calculate an objective probability distribution to support premium calculations. If a risk cannot be priced with a reasonable degree of precision, the risk is difficult to insure.

Although these two characteristics are the salient ones, difficult risks also tend to have other common features. For example, when coverage is offered for difficult risks, there is often a lack of demand to purchase it. This somewhat counterintuitive point derives from the fact that relatively few people voluntarily protect themselves against a hazard unless they have previous experience with it or know someone who has. This experience is often absent with difficult risks because of their relative infrequency. When this experience is absent, purchasing insurance for these risks appears to lack value, and take-up rates are low ${ }^{61}$.

The take-up rate problem is tied to another feature of difficult risks. Difficult risks tend to have long time horizons, and this creates a mismatch between smooth premium collections and highly unsmooth loss payments. For example, if a $\$ 100$ billion earthquake happens (on average) once every 40 years, but the exact timing is unknown (and the possibility exists that two might happen within 10 years while none happens during an 80 -year period), calculating the fair and adequate premium over these long time horizons is difficult.

Difficult risks are sometimes described as risks that are uninsurable. If "uninsurable" is understood to refer to risks where the maximum possible loss is beyond the capital capacity of the insurance industry (i.e., paying the loss would lead to insolvency), the definition is cor-

61 This has been the experience in the U.S. with earthquake and flood insurance. In the immediate aftermath of these events, the media will discuss the amount of uninsured loss, and the importance of better risk management practices will have salience in public discussions. As time passes, however, the populace moves on to seemingly more urgent problems, and preparations for the next earthquake or flood assume lower priorities. As interest fades, insurance purchases decline, which leads to uninsured loss when the next event occurs. Beyond the heuristic that causes low take-up rates, some evidence suggests that the media's coverage of disaster relief efforts leads to a popular assumption that the government will come to the aid of the populace ex poste through disaster relief aid, which deters ex ante purchases of insurance. For more discussion, see Jones \& Baumgartner (2005). 
rect. But portions of uninsurable risks can be transferred and distributed in insurance markets when coverage limits, inter-regional diversification, and global diversification via reinsurance are utilized to limit company and industry exposures. In addition, management of difficult risks is aided by improved technologies that allow better predictions of the amount and frequency of loss, and by the creation of innovative, technology-assisted strategies that assist with risk transfer and distribution ${ }^{62}$. Although war is considered the classic uninsurable risk, niche coverage is available in markets for war, terrorism, political risk, riots, and commotion risks ${ }^{63}$. When government backstops and risk securitization is added to the equation, the power to manage difficult risks becomes substantial (Schwarcz, 2020, 15 October).

Natural disasters and terrorism are both examples of difficult risks, and the limitations of private markets to manage these risks without government intervention has received much attention in recent years. As these markets have evolved, government backstops for catastrophic risk have helped private markets function more effectively. That being said, it is obvious that these perils differ from pandemics in important ways. Natural disasters and terrorism have geographic limitations; a hurricane, for example, will not flood the entire planet ${ }^{64}$. Terrorism events happen in a particular place at a particular time, and the effects of the event, even if severe, are confined both geographically and temporally. This is important because these difficult risks produce relatively concentrated results, making them capable of management in private markets via inter-regional diversification, reinsurance, and government backstops as necessary. Investor interest via insurance-linked securities can also assist with the management of these risks.

Some perils, however, can be manifested in events of massive size that lack geographic boundaries and possess extremely long event-to-remediation timelines. These risks are so vast that they overwhelm private risk transfer and distribution mechanisms and even challenge the strength of governmental institutions as the insurer of last resort. These difficult risks are properly labeled "systemic risks", denoting a category of perils within the set of difficult risks that, if they become manifest, place potentially cataclysmic stress on risk-spreading mechanisms of every kind.

The classic examples of systemic risk are global warfare ${ }^{65}$, climate change ${ }^{66}$, terrorism (cyber, biological, or nuclear) directed at critical infrastructure (such as energy supplies) ${ }^{67}$, and mega-

62 See, e.g., Sherman (2019, 31 May); Verisk, Catastrophe Management (undated), https://www.verisk.com/ insurance/capabilities/weather-risk/catastrophe-management/ (accessed 4 Dec. 2020) (discussing products, services, and models to assist insurers with reserving decisions and risk transfer alternatives).

63 See, e.g., Clements, Political Risk, Violence, War and Terrorism Insurance (undated), https://www.clements.com/insurance-solutions/your-organization/commercial-solutions/political-riskspolitical-violence-war-and-terrorism-insurance-coverage (accessed 4 Dec. 2020) (describing products offered); Lockton, War \& Terrorism Insurance (undated), https://www.lockton.com/war-terrorism (accessed 4 Dec. 2020) (describing products offered).

64 This observation must be qualified by the reality that the planet has suffered in the past, and remains vulnerable to, catastrophic disasters than would challenge the existence of life as we know it. Examples include a large asteroid or the eruption of a mega-volcano that blankets the earth in ash.

65 See, e.g., Magarick \& Brownlee (2020, \$50:13), discussing common exclusions for war, terrorism, and nuclear events; Wall et al. (2020, $\$ \$ 14: 2$ et seq.), discussing war risk exclusions. 
natural disasters ${ }^{68}$. With respect to these perils, a total mismatch exists between likely economic losses and the capacity of insurers to take on the risk.

Pandemic is another example of systemic risk. With respect to COVID-19, the World Bank estimates global GDP loss for 2020 at USD 4.5 trillion $^{69}$. Less than one percent of this loss will be covered by business interruption insurance, for which insurers collected about USD 30 billion in premium, which itself accounts for less than two percent of premium in the entirety of the world's property and casualty insurance market. This mismatch between economic losses and insurance coverage is staggering, but the sobering ratio embedded in these numbers is that the industry would need to collect the current year's business interruption premiums for 150 years to cover 2020 GDP losses. Stated otherwise, global premiums in 2020 for all property and casualty insurance was USD 1.6 trillion, which is barely one-third of the business continuity loss in the first year of the COVID-19 pandemic. Covering all pandemic-induced business interruption losses in private markets is not possible.

However, as with difficult risks, portions of pandemic-induced business interruption risk can be covered in private markets. Insurers should be able to model products that provide limited coverage, both in terms of total proceeds paid and the duration of a business interruption subject to coverage ${ }^{70}$. Parametric insurance products are particularly promising ${ }^{71}$. Traditional insurance pays proceeds based on the amount of the loss as determined in a claims adjustment process. In contrast, parametric insurance pays out when a pre-defined event occurs and it meets an objective triggering standard, or index. These triggers are beyond the insured's control, which is an important consideration, given that when triggers are influenced or controlled by policyholders (as can happen with, for example, some forms of event cancellation insurance), moral hazard can come into play $^{72}$. Thus, parametric hurricane insurance would pay when a specified wind speed is reached in a particular area; parametric flood insurance would pay when floodwaters reach a certain height; and parametric business interruption insurance would pay when the number of infections, or hospitalizations, or deaths in a particular geography in which the insured's assets are located meet designated thresholds. The insurer's exposure is limited through an attachment point which defines when the coverage

66 See, e.g., Morton (2020, 27 April). Insurers will adapt to the climate change threat, but reductions in the availability and scope of coverage along with increases in premiums will be a part of this equation. See, e.g., Broberg (2017); Golnaraghi (2018, January).

67 See Wall et al. (2020). The cyber risk resembles pandemic risk in that malware can spread around the globe quickly through interconnected networks, which explains why destructive malware is commonly referred to as a "computer virus".

68 See, e.g., Blackett (2015, 1 October), discussing supervolcanoes, mega-tsunamis, and solar flare); Jerry, II (2019), discussing different kinds of catastrophes and their probabilities.

69 Id. (citing World Bank data).

70 The BOP already has a duration limit. See discussion in the text accompany n. 66, supra.

71 See, e.g., Horton (2018); Grant (2020, 7 May); Banham (2020, 3 April).

72 It has been suggested that the reason the Wimbledon tennis tournament and the British Open golf tournament were cancelled, whereas the French Open and U.S. Open tennis tournaments were postponed, is that the sponsors of Wimbledon and the British Open had purchased event cancellation insurance, and the sponsors of the French Open and U.S. Open had not. See, e.g., Dunlap (2020, 20 July, p. 5): "any solution involving the financing of pandemic-driven business continuity losses will necessarily require widespread government protection”. 
begins, and caps limit the maximum exposure. With parametric insurance, a risk exists that the insured will suffer damage before the coverage is triggered (this is called "basis risk"), and thus traditional coverage is still necessary for losses suffered before parametric coverage applies, but the parametric layer should create a potential for traditional products to function in the first layers of coverage.

Although the private market can play a role in managing pandemic risk, the fact remains that coverage gaps for the massive losses in these systemic events cannot be managed in a private market alone. The next question is what role government should play in supporting private insurance for systemic risk in its status as the insurer of last resort (Hartwig \& Gordon, 2020).

\subsection{A Governmental Role in Difficult and Systemic Risk Management}

In recent decades, the insurance industry and governments throughout the world have cooperated to manage the difficult risks of flood, earthquake, hurricane, and terrorism. These efforts have resulted in an array of designs for private-government partnerships that essentially fall into four categories. Under one approach, government becomes the sole insurer, assumes 100 percent of the risk, displaces private insurers for all purposes, and takes over all enrollment and claims adjustment processes ${ }^{73}$. Another approach has the government assume 100 percent of the risk and displace all risk-spreading in the private markets, but has private insurers take applications, collect premiums, and perform claim adjustment ${ }^{74}$. A third approach has the government create an insurance company that sells reinsurance at discounted rates (thereby causing the government to insure a share of the risk beyond that covered in private markets). Under this approach, variations can exist in how the reinsurance level is funded, which can adjust the risk-sharing arrangement between private insurers and the government. For example, if private insurers are compelled to participate in the funding of this company, this would have the effect of pooling the industry's risk while capping industry losses ${ }^{75}$. A fourth approach has private insurers cover a primary layer of coverage until an industry deductible is met, at which point the federal government takes over the 100 percent of the risk beyond the deductible. Variations in this approach can also be created that adjust the level of industry

73 In the U.S., this is essentially what the government has done with health insurance for the elderly through the Medicare program enacted in 1965. The federal government is, with an important exception, the sole insurer operating in a single-payor system. The exception is what is now known as Medicare Part C, or "Medicare Advantage", which as first allowed in demonstration projects in the 1970s and then was formally introduced into the program in 1997 , allows private plan sponsors to offer what are essentially managed care plans in lieu of the traditional government-underwritten Medicare plan (Parts A and B).

74 In the U.S., this is essentially what the government has done with the flood insurance risk through the 1968 National Flood Insurance Program. For details on the structure of the program, see FEMA, Flood Insurance Rules and Legislation, 18 July 2020, https://www.fema.gov/flood-insurance/rules-legislation (accessed 1 Dec. 2020).

75 In the U.S., a good example of this structure was a temporary reinsurance program established as part of the Affordable Care Act and which operated from 2014 to 2016. Under this program, the federal government made payments to individual market plans when the annual cost for an enrollee exceeded a specified amount. Several states implemented reinsurance programs modeled on the ACA program when the temporary program expired. See Lueck (2019, 3 April). Another example is the Florida Hurricane Catastrophe Fund, which is a state trust fund that provides reinsurance for insurers writing residential insurance; it was created in 1993 following Hurricane Andrew, which at that time was the largest disaster, measured in terms of insured loss, in U.S. history. See Florida Hurricane Catastrophe Fund, https://www.sbafla.com/fhcf/ (accessed 3 Dec. 2020). 
participation until the government assumes 100 percent of the risk. This backstop approach is functionally the equivalent of the reinsurance alternative, except that the insurance industry pays none of the premium for the reinsurance layer beyond the deductible ${ }^{76}$.

In 2020, policymakers around the world, with the involvement of industry and others, are exploring solutions for covering pandemic-caused business interruption loss (OECD, 2020, 9 September, pp. 3-6, 10-20). In the U.S., as of December 2020, two proposals are pending in the Congress that would formalize a government role in the management of pandemic risk. The Pandemic Risk Insurance Act (PRIA) ${ }^{77}$ follows a reinsurance model with similarities to the federal statute enacted in 2002 under which the federal government provides a backstop to insurers' coverage of the terrorism risk. Under the proposed PRIA, property and casualty insurers can choose whether to participate in the program, but if they do, they must offer policyholders business interruption insurance coverage for losses caused by pandemic. Each participating insurer would be liable for 100 percent of losses up to an insurer-specific deductible (set at five percent of direct earned premium (DEP) for the prior year); beyond that layer, the insurer is liable for five percent of losses up to a $\$ 500$ billion aggregate industry limit. For aggregate losses exceeding $\$ 250$ million, the federal government would provide reinsurance; insurers would be charged premiums for participation in the reinsurance layer at levels intended to reflect the actuarial value of the reinsurance. As proposed, PRIA would cap the total federal governmental contribution at $\$ 750$ billion. PRIA has the support of many industries, including the retail and travel industries, and a large proportion of the risk management community.

Insurance industry groups have proposed an alternative that is modeled on the U.S. National Flood Insurance Program (NFIP) ${ }^{78}$. Under the proposed Business Continuity Protection Program (“BCPP”) ${ }^{79}$, businesses would purchase FEMA-administered protection agreements through voluntarily participating insurers. Upon the issuance of a presidential viral emergency declaration, payments under the agreements would be triggered automatically, and (unlike the flood program) no claims adjustment would occur. Under BCPP and like the

76 In the U.S., this is essentially how the Terrorism Risk Insurance Act of 2002 functions. In general terms, the insurance industry covers 100 percent of small losses; Medium-sized losses (above a threshold) are paid by the federal government initially, with a round of recoupment of a portion of the payments from insurers. As losses grow larger, the amount of recoupment allowed declines. Eventually, the federal government is not required to obtain any recoupment, which is the functional equivalent of the government providing a total backstop. See Cong. Res. Serv., Terrorism Risk Insurance: Overview and Issue Analysis for the 116th Congress, 27 Dec. 2019, https://www.ncci.com/Articles/Pages/II_Terrorism-Risk-Insurance-OverviewIssue-Analysis-116th-Congress-CRS-2019.pdf (accessed 3 Dec. 2020).

77 For text of the bill, see H. R. 7011-Pandemic Risk Insurance Act of 2020, 116th Cong. (2019-20), https:// www.congress.gov/bill/116th-congress/house-bill/7011/text (accessed 3 Dec. 2020). For a section by section summary of the bill, see Pandemic Risk Insurance Act Section-by-Section, https://maloney.house.gov/sites/ maloney.house.gov/files/PRIA\%20Section\%20by\%20Section.pdf (accessed 3 Dec. 2020). The principal drafter and promoter of this proposed legislation is Rep. Carolyn Maloney (D-NY). Rep. Maloney convened hearings on the bill on 19 Nov. 2020; see, e.g., Sistrunk (2020, 19 November).

78 For details on the NFIP, see FEMA, National Flood Insurance Program, https://www.floodsmart.gov/ (accessed 5 Dec. 2020).

79 The BCPP, which was also discussed in the 19 Nov. 2020 hearings, is promoted by the American Property Casualty Insurance Association, the National Association of Mutual Insurance Companies, and the Independent Insurance Agents \& Brokers of America. See Sclafane (2020, 21 May); Sclafane (2020, 20 November). 
NFIP, the insurance industry would bear no risk; 100 percent of the risk would be borne by the federal government. Under the agreements, participating businesses would receive a payment equal to 80 percent of three months of payroll and operating expenses based on the prior year's federal tax returns. Like PRIA, BCPP would cap the federal government's payments at $\$ 750$ billion. FEMA would be authorized to purchase private reinsurance to cover portions of the federal government's payments.

\subsection{Toward a Comprehensive Global Preparedness Framework}

Because the consequences of a global pandemic are so vast, strategies to deal with them must be varied, interdependent, and coordinated. In other words, a comprehensive global preparedness framework is necessary (Gostin, 2020, 13 August). Establishing a coherent framework of effective strategies for any disaster begins with the recognition that multiple core missions will exist within the framework: prevention; protection; mitigation; response; and recovery ${ }^{80}$. Prevention describes efforts designed to avoid the occurrence of a disaster. Protection refers to securing and hardening the means through which a government defends its citizens, property, systems, networks, and other assets from the effects of a disaster as they unfold. Mitigation, which is closely related to protection, refers to steps taken in advance of a disaster to reduce the impact of an outbreak on people and property. Response refers to actions government takes as a disaster unfolds to save lives, protect property, and meet human needs. Recovery refers to restoring and rebuilding in the aftermath of an occurrence.

In the context of a pandemic, prevention embraces efforts designed to prevent the outbreak of a pandemic or, if it occurs, to confine it and prevent its spread. Protection refers to securing in advance the facilities, tools, devices, medicines, diagnostics, staffing, and other assets necessary to defend people against the effects of an outbreak once it happens. Mitigation refers to efforts to reduce the impact of an outbreak; this mission is furthered by investments in public health, including vaccine research. Response refers to actions government takes as a pandemic unfolds to save lives, protect property, maintain economic activity, and meet human needs in other words, a specific plan of implementation of government actions to protect the public. Recovery refers to restoring and rebuilding in the aftermath of the pandemic. This includes rebuilding the prevention, protection, mitigation, and response infrastructures, stimulating the economy and addressing the economic losses suffered by businesses and individuals, and assisting with the long-term health care needs of those who survive the pandemic but suffer long-term deficiencies as a result of it.

Insurance can be an important part of this framework, but the reality is that it is destined to be a small part. Partial coverage of business continuity risk in private markets with supplemental government insurance commitments is an example of ex ante planning to mitigate financial loss. When proceeds are paid, insurance aids the recovery mission. Insurers' risk management expertise will be useful to some extent to help businesses understand steps they can take to reduce pandemic risk, meet safe distancing requirements, minimize losses during a pandem-

80 For a discussion of how these core missions are understood in the context of the U.S. national preparedness policy, see U.S. Dep't of Homeland Security, 2018 National Preparedness Report, 2018 National Preparedness Report (fema.gov) (accessed 1 Dec. 2020). 
ic, and safely expedite resumption of business activities ${ }^{81}$. The possibility exists that insurers' claims processing systems can be deployed to move assistance and stimulus funds to businesses that suffered losses ${ }^{82}$.

At the beginning of 2021, the focus must be on getting through the COVID-19 tunnel and emerging safely on the other side. The total costs and losses this pandemic will cause are unknown and still growing, but we will eventually exit this tunnel. History and science, however, teach us that pandemics reoccur, that the most lethal and virulent have the potential to disrupt civilizations and change the course of history ${ }^{83}$, and that growing population densities and ease of global movement are increasing the pandemic risk (Kaneda \& Greenbaum, 2020, 13 April) even as science, technology, and innovation increase the ability of humankind to prevent, contain, and treat pandemics (Jester, Uyeki, Patel, Koonin, \& Jernigan, 2018) ${ }^{84}$. Putting aside the question of whether the lessons of the 1918 influenza pandemic were learned, it is incumbent that we learn the lessons of the 2020 coronavirus pandemic and create a comprehensive framework, including insurance, to better prepare the world for whatever pandemics await us in the future ${ }^{85}$.

\section{References}

Amaro, S. (2020, October 13). IMF Revises its global GDP forecast higher, but warns the economy 'remains prone to setbacks'. CNBC. Retrieved from: https://www.cnbc.com/2020/10/13/imf-world-economic-outlook-2020-amidcoronavirus-crisis.html (last accessed 3 Nov. 2020).

Baker, T. (2020, December 2). More than 15\% of BI insurance cases have been terminated already, mostly voluntarily. Retrieved from: https://cclt.law.upenn.edu/2020/12/02/ more-than-15-of-bi-cases-have-been-terminated-already-mostly-voluntarily (last accessed 4 Dec. 2020).

Banham, R. (2020, April 3). This Insurance Would Have Helped in Coronavirus Crisis But Nobody Bought It. Insurance Journal. Retrieved from: https://

81 See Dixon \& Saunders-Medina (2020, 26 June), discussing advantages of private insurance as method of compensating pandemic losses).

$82 \mathrm{Id}$. With parametric insurance, for example, benefits are determined in advance, and once the trigger is reached, payments are made. Utilizing this product for a portion of the business interruption risk could reduce delays that occur in traditional claims adjustment systems and the pitfalls that exist when government disbursement programs are hastily constructed in the aftermath of a disaster.

83 See, e.g., History.com (2020, 1 April); Huremovic (2019, 16 May).

84 Discussing accomplishments in pandemic response and treatment since 1918.

85 For a prescient analysis of the pandemic risk and a call for increased preparations, see Sands et al. (2020). This report begins: "On the 100th anniversary of the 1918 influenza pandemic, it is tempting to believe the world has seen the worst epidemics. However, with increasing trade, travel, population density, human displacement, migration and deforestation, as well as climate change, a new era of the risk of epidemics has begun. The number and diversity of epidemic events has been increasing over the past 30 years, a trend that is only expected to intensify" (Sands et al., 2020, p. 6). 
www.insurancejournal.com/news/national/2020/04/03/563224.htm (last accessed 3 Dec. 2020).

Barry, J. M. (2004). The site of origin of the 1918-1919 influenza pandemic and its public health implications. Journal of Translational Medicine, 2(3). doi: $10.1186 / 1479-5876-2-3$.

BDO US (2020, April). The Financial Reporting and Accounting Impact on Insurers Due to the COVID-19 Pandemic. Retrieved from: https://www.bdo.com/insights/industries/insurance/the-financial-reporting-and-accounting-impact-on-i (last accessed 4 Nov. 2020).

Blackett, M. (2015, October 1). Five global catastrophes that could happen tomorrow. The Conversation. Retrieved from: https://theconversation.com/five-global-catastrophes-that-could-happen-tomorrow-48420 (last accessed 1 Dec. 2020).

Blanco, S. (2020, October 1). U.S. Traffic Deaths Lowest Since 204, but 2020 Numbers Aren't Looking Good. Car and Driver. Retrieved from: https://www.caranddriver.com/ news/a34240145/2019-2020-traffic-deaths-coronavirus/ (last accessed 4 Nov. 2020).

Bonner, M. (2019, May 16). Insurance Services Office (ISO). Retrieved from: https:// www.thebalancesmb.com/insurance-services-office-iso-462706 (last accessed 4 Dec. 2020).

Broberg, M. (2017). Risk Regulation and the Future: On the Need for Helping Vulnerable Societies to Adapt to the Consequences of Climate Change. European Journal of Risk Regulation, 8(1), 101-105. doi: 10.1017/err.2016.17.

Byrne, F., Gray, L., Kaissar, T., Rehmani, Z., Rose, A., \& van Vuuren, M. (2020). KPMG, Making sense of solvency, capital and COVID-19 for the insurance sector. Retrieved from: https://home.kpmg/xx/en/home/insights/2020/04/covid-19-solvency-capital-and-the-insurance-sector.html (last accessed 4 Nov 2020).

Childress, R. (2020, November 1). The New Business Essentials for Meetings. Now Associations. Retrieved from: https://associationsnow.com/2020/11/the-new-business-essentials-for-meetings/ (last accessed 18 Nov 2020).

Church, S., \& Hill, J. (2020, September 11). Interruption Insurance Isn't Saving Anyone From Shutdowns. Bloomberg. Retrieved from: https://www.bloomberg.com/news/articles/2020-09-11/interruption-insurance-isn-t-saving-anyone-from-covid-shutdowns (last accessed 24 Nov 2020).

Clancy, T. (1995). Debt of Honor. New York: Berkley Books.

Congressional Research Service (2020, September 21). The PREP Act and COVID-19: Limiting Liability for Medical Countermeasures. Retrieved from: https:// crsreports.congress.gov/product/pdf/LSB/LSB10443 (last accessed 19 Nov 2020).

Cutler, D. M., \& Summers, L. H. (2020, October 12). The COVID-19 Pandemic and the \$16 Trillion Virus. JAMA, 324(15), 1495-1496. doi: 10.1001/jama.2020.19759. 
D’Orlando, M. C. (2012). The Businessowners Policy. Vermont: Union Mutual of Vermont. Retrieved from: http://www.massagent.com/events/12manuals/bop_handout.pdf (last accessed 22 Nov 2020).

Davis, S. B., \& Grossman, J. D. (2020, March 20). Business Insurance Considerations during the COVID-19 Pandemic. Stradnley Ronon Insurance Practice Group Client Alert. Rpt. PCL 1624866 (C.C.H.).

Dayen, D. (2020, September 11). Business, Interrupted. The American Prospect. Retrieved from: https://www.nytimes.com/2020/08/05/business/business-interruption-insurance-pandemic.html (last accessed 23 Nov 2020).

DiMugno, J. (2020, June). The Implications of COVID-19 for the Insurance Industry and Its Customers. Cal. Ins. L. छ Reg. Rep., NL 1.

DiMugno, J. (2020, November 6). The Implications of COVID-19 for the Insurance Industry and Its Customers: An Update. Ins. Lit. Rptr, 42, NL 1.

Dixon, L., \& Saunders-Medina, B. (2020, June 26). Is It Time for a Federal Pandemic Insurance Program? Rand Blog. Retrieved from: https://www.rand.org/blog/2020/06/isit-time-for-a-federal-pandemic-insurance-program.html (last accessed 1 Dec. 2020).

Donald, J. W. (2020, April 20). D\&O Insurance Coverage and Coronavirus: Avoiding Exclusions. Insurance Journal. Retrieved from: https://www.insurancejournal.com/magazines/mag-features/2020/04/20/565221.htm (last accessed 19 Nov. 2020).

Dorratoltaj, N., \& Fullam, D. (2018, March 29). What the 1981 Flu Pandemic Can Teach Today's Insurers. AIR. Retrieved from: https://www.air-worldwide.com/publications/air-currents/2018/Whatthe-1918-Flu-Pandemic-Can-Teach-Today-s-Insurers/ (last accessed 25 Nov. 2020).

Drexler, M. (2010). What You Need to Know about Infectious Diseases. Washington, DC: National Academies Press. Retrieved from: https://www.ncbi.nlm.nih.gov/books/ NBK209710/ (last accessed 23 Nov. 2020).

Dunlap, K. (2020, July 20). Why were Wimbledon, British Open canceled instead of postponed? Retrieved from: https://www.ksat.com/sports/2020/07/20/why-were-wimbledon-british-open-canceled-instead-of-postponed/ (last accessed 2 Dec. 2020).

Fischetti, M. (2001, October). Drowning New Orleans. Scientific American.

French, C. C. (2014). The Aftermath of Catastrophes: Valuing Business Interruption Insurance Losses. Georgia State Law Review, 30(2), 461-520. doi: 10.2139/ssrn.2203695.

French, C. C. (2020). COVID-19 Business Interruption Insurance Losses: The Cases For and Against Coverage. Connecticut Insurance Law Journal, 27(1), 1-35.

Furbell, T. V. (1919). The Effect of Influenza on Insurance. NAIC Proceedings, 302-311.

Gangopadhyaya, A., Karpman, M., \& Aarons, J. (2020, September 17). As COVID-19 Recession Extended Into Summer 2020, More Than 3 Million Lost Employer-Sponsored Health Insurance Coverage and 2 Million Became Uninsured. Urban Institute. Retrieved from: https://www.rwjf.org/en/library/research/2020/09/as-covid-19-recession-extend- 
ed-into-summer-2020-more-than-3-million-lost-employer-sponsored-healthinsurance.html (last accessed 19 Nov. 2020).

Golnaraghi, M. (2018, January). Climate Change and the Insurance Industry: Taking Action as Risk Managers and Investors. Geneva: Geneva Association. Retrieved from: https://www.genevaassociation.org/sites/default/files/research-topics-document-type/pdf_public/climate_change_and_the_insurance_industry_-

_taking_action_as_risk_managers_and_investors.pdf(last accessed 1 Dec. 2020).

Gostin, L. O. (2020, August 13). The Great Coronavirus Pandemic of 2020-7 Critical Lessons. JAMA Health Forum. doi: 10.1001/jamahealthforum.2020.1043.

Grant, M. (2020, May 7). Parametric Insurance: Is It the Future? Retrieved from: https:// www.insurancethoughtleadership.com/parametric-insurance-is-it-the-future/ (last accessed 3 Dec. 2020).

Grzadkowska, A. (2020, August 13). COVID-19 'hastens the pace' of hardening market in D\&O. Insurance Business America. Retrieved from: https://www.insurancebusinessmag.com/us/news/professional-liability/covid19hastens-the-pace-of-hardening-market-in-dando-230680.aspx (last accessed 19 Nov. 2020).

The Guardian (2020, December 1). Covid world map: which countries have the most coronavirus cases and deaths? Retrieved from: https://www.theguardian.com/world/2020/dec/01/covid-world-mapwhich-countries-have-the-most-coronavirus-cases-and-deaths (last accessed 1 Dec. 2020).

Hartwig, R., \& Gordon, R. (2020). Uninsurability of Mass Market Business Continuity Risks from Viral Pandemics. Retrieved from: http://www.pciaa.net/docs/default-source/ default-document-library/apcia-white-paper-hartwig-gordon.pdf (last accessed 3 Dec. 2020).

Hay, L. J. (2020). Do Insurers have COVID-19 covered? KPGM. Retrieved from: https://home.kpmg/xx/en/home/insights/2020/03/do-insurers-have-covid-19covered.html (last accessed 25 Nov. 2020).

Hishamunda, H. N., \& Young, K. M. (2020, October 29). COVID-19 Liability Shields: Today's Legislative Trend, Tomorrow's Legal Defense. Seyfarth Legal Update. Retrieved from: https://www.seyfarth.com/news-insights/covid-19-liability-shields-todays-legislative-trend-tomorrows-legal-defense.html (last accessed 19 Nov. 2020).

History.com (2020, April 1). Pandemics That Changed History. Retrieved from: https:// www.history.com/topics/middle-ages/pandemics-timeline (last accessed 1 Dec. 2020).

Hoffman, K. E. (2020, September 10). Business Interruption: Insurers Balk at Paying Claims. Risk Management. Retrieved from: https://www.cfo.com/risk-management/2020/09/pandemic-losses-out-in-the-cold/ (last accessed 22 Nov. 2020).

Horton, J. B. (2018). Parametric Insurance as an Alternative to Liability for Compensating Climate Harms. Carbon E' Climate Law Review, 12(4), 285-296. doi: 10.21552/ cclr/2018/4/4. 
Huremovic, D. (2019, May 16). Brief History of Pandemics. Psychiatry of Pandemics, 7-35. doi: 10.1007/978-3-030-15346-5_2.

International Monetary Fund (2020, October). World Economic Outlook, October 2020: A Long and Difficult Ascent. Retrieved from: https://www.imf.org/en/Publications/WEO/Issues/2020/09/30/world-economic-outlook-october-2020\#Full\%20Report\%20and\%20Executive\%20Summary (last accessed 3 Nov. 2020).

Insurance Information Institute (2020). Insurance Fact Book. Retrieved from: https://www.iii.org/publications/2020-insurance-fact-book/life-annuity-financial-data/financial-results (last accessed 19 Nov. 2020).

Jerry, II, R. H. (2019). Managing Hurricane (and Other Natural Disaster) Risk. Texas A EM Law Review, 6(2), 391-452. doi: 10.37419/LR.V6.I2.3.

Jerry, II, R. H., \& Richmond, D. R. (2018). Understanding Insurance Law (6 ${ }^{\text {th }}$ ed.). Durham: Carolina Academic Press.

Jester, B. J., Uyeki, T. M., Patel, A., Koonin, L., \& Jernigan, D. B. (2018, November). 100 Years of Medical Countermeasures and Pandemic Influenza Preparedness. American Journal of Public Health, 108(11), 1469-1472. doi: 10.2105/AJPH.2018.304586.

Jones, B. D., \& Baumgartner, F. R. (2005). The Politics of Attention: How Government Prioritizes Problems. Chicago: University of Chicago Press.

Jones, S. K. (2020, September 21). Agents Warned of 'Creative' Attorneys and COVID-19 Lawsuits. Insurance Journal. Retrieved from: https://www.insurancejournal.com/magazines/mag-features/2020/09/21/583090.htm (last accessed 19 Nov. 2020).

Kaneda, T., \& Greenbaum, C. (2020, April 13). How Demographic Changes Make us More Vulnerable to Pandemics Like the Coronavirus. Population Reference Bureau. Retrieved from: https://www.prb.org/how-demographic-changes-make-us-more-vulnerable-to-pandemics-like-the-coronavirus/ (last accessed 1 Dec. 2020).

Kimball, S. L. (1960). Insurance and Public Policy. Madison: University of Wisconsin Press.

Kirti, D., \& Shin, M. Y. (2020, June 20). The impact of COVID-19 on insurers. Retrieved from: https://voxeu.org/article/impact-covid-19-insurers (last accessed 4 Nov. 2020).

Krekstein, B., \& McGowan, E. (2014, February). Anti-Concurrent Causation Clauses in Property Policies. GenRe Research. Retrieved from: https://www.genre.com/knowledge/publications/pm1402-35-en.html (last accessed 4 Dec. 2020).

Lewis, R. P., Ellison, J. N., \& Debevec, L. E. (2020, April 7). Here we go again: Virus exclusion for COVID-19 and insurers. NU Property Casualty, 360.

LiMandri, C. S. et al. (2020, June 19). Business Interruption Coverage for the COVID-19 Pandemic: Insurance Industry Fights Biggest Battle Ever Against Difficult Odds. Ins. Lit. Rptr, 42 NL1.

Lueck, S. (2019, April 3). Reinsurance Basics: Considerations as States Look to Reduce Private Market Premiums. Retrieved 
from: https://www.cbpp.org/research/health/reinsurance/reinsurance-basics-considerations-as-states-look-to-reduce-private-market-premiums (last accessed 3 Dec. 2020).

Magarick, P., \& Brownlee, K. (2020). Casualty Insurance Claims (4 $4^{\text {th }}$ ed.). Eagan: Thomson Reuters.

Malecki, D. S. (2011, March). Japan Earthquake a Wake-Up Call for Contingent Business Interruption Coverage. Adjusting Today. Retrieved from: https:// www.adjustersinternational.com/publications (last accessed 4 Dec. 2020).

Masters, L. S., \& Ellis, L. M. (2020, August 10). Event Cancellation Insurance Issues During a Pandemic. National Law Review. Retrieved from: https://www.natlawreview.com/article/event-cancellation-insurance-issues-during-pandemic (last accessed 18 Nov. 2020).

Masters, L. S., \& Levin, M. S. (2020, March 18). First Suit to Enforce Business-Interruption Coverage Filed. Hunton Andrews Kurth. Retrieved from: https://www.huntoninsurancerecoveryblog.com/2020/03/articles/event-cancellation/first-suit-to-enforce-business-interruption-coverage-filed/ (last accessed 24 Nov. 2020).

McFadin, C. (2020, October 6). Auto insurers' refund responses during the first COVID-19 wave. NU Property Casualty 360. Retrieved from: https://www.propertycasualty360.com/2020/10/06/a-look-at-auto-insurers-responses-to-the-first-covid-19-wave/ (last accessed 4 Nov. 2020).

Modzelewski, C. F. (2020). The Constitutional Unsoundness of Retroactively Legislating Business Interruption Coverage for Covid-19. ABA Lit. Sect. Retrieved from: https://www.americanbar.org/groups/litigation/committees/insurance-coverage/articles/2020/constitutional-unsoundness-retroactive-business-interruption-coverage/ (last accessed 23 Nov. 2020).

Moorcraft, B. (2020, June 15). Retroactive business interruption measures could bankrupt US insurers in two month. Insurance Business. Retrieved from: https://www.insurancebusinessmag.com/us/news/breaking-news/retroactive-business-interruption-measures-could-bankrupt-us-insurers-in-twomonths-225240.aspx (last accessed 24 Nov. 2020).

Morton, A. (2020, April 27). Climate crisis will make insurance unaffordable for people who need it most. The Guardian. Retrieved from: https://www.theguardian.com/australia-news/2020/apr/28/climate-crisis-willmake-insurance-unaffordable-for-people-who-need-it-most (last accessed 1 Dec. 2020).

OECD (2020, July 2). Insurance sector responses to COVID-19 by governments, supervisors and industry. Retrieved from: http://www.oecd.org/pensions/Insurance-sector-responses-to-COVID-19-by-governments-supervisors-and-industry.pdf(last accessed 4 Nov. 2020).

OECD (2020, September 9). Responding to the COVID-19 and pandemic protection gap in insurance. Retrieved from: https://www.oecd.org/coronavirus/policy-responses/responding-to-the-covid-19-and-pandemic-protection-gap-in-insurance-35e74736/ (last accessed 3 Dec. 2020). 
Okpewho, U. (2020, August). Financial Impacts of COVID-19 on Health Insurers. BDO. Retrieved from: https://www.bdo.com/insights/industries/insurance/financial-impacts-of-covid-19-on-health-insurers (last accessed 19 Nov. 2020).

Racicot, F., \& Spidell, B. (2018, November). Presumptive Coverage for Firefighters and Other First Responders. NCA Research Brief. Retrieved from: https://www.ncci.com/Articles/Documents/Insights-Research-Brief-Presumptive-Coverage.pdf (last accessed 21 Nov. 2020).

Ramirez, G., Amin, K., \& Cox, C. (2020, October 21). The pandemic's effect on the widening gap in mortality rate between the U.S. and peer countries. Peterson-KFF Health System Tracker. Retrieved from: https://www.healthsystemtracker.org/brief/the-pandemics-effect-on-the-widening-gap-in-mortality-rate-between-the-u-s-and-peer-countries/ (last accessed 19 Nov. 2020).

Richter, A., \& Wilson, T. C. (2020). Covid-19: Implications for insurer risk management and the insurability of pandemic risk. The Geneva Risk E' Insurance Review, 45, 171-199. doi: 10.1057/s10713-020-00054-z.

Riddel, S., Goldie, S., Hill, A., Eagles, D., \& Drew, T. W. (2020, October 7). The effect of temperature on persistence of SARS-CoV-2 on common surfaces. Virology Journal, 17. doi: 10.1186/s12985-020-01418-7.

Sams, J. (2020, November 12). Nation's $1^{\text {st }}$ COVID-19 Business-Interruption Suit Headed to Trial. Claims Journal. Retrieved from: https://www.claimsjournal.com/news/ national/2020/11/12/300415.htm (last accessed 24 Nov. 2020).

Sands, P. et al. (2020). Outbreak Readiness and Business Impact: Protecting Lives and Livelihoods across the Global Economy. World Economic Forum. Retrieved from: https:// www.weforum.org/reports/outbreak-readiness-and-business-impact (last accessed 3 Dec. 2020).

Schanz, K. U., Eling, M., Schmeiser, H., \& Braun, A. (2020). An Investigation into the Insurability of the Pandemic Risk. Geneva: Geneva Association. Retrieved from: https://www.genevaassociation.org/sites/default/files/research-topics-document-type/pdf_public/insurability_report_web.pdf(last accessed 19 Nov. 2020).

Schwarcz, S. L. (2020, October 15). Insuring the "Uninsurable": Catastrophe Bonds, Pandemics, and Risk Securitization. Duke Law School Pub. Law Ev Legal Theory Series, 2020-71. doi: 10.2139/ssrn.3712534.

Sclafane, S. (2020, May 21). Insurance Groups Team Up on Federal 'Business Continuity Protection Program'. Carrier Management. Retrieved from: https:// www.carriermanagement.com/news/2020/05/21/206991.htm (last accessed 3 Dec. 2020).

Sclafane, S. (2020, November 20). What Congress Should Do, or Not Do, to Rescue Businesses in Future Pandemics. Insurance Journal. Retrieved from: https:// www.insurancejournal.com/news/national/2020/11/20/591467.htm (last accessed 3 Dec. 2020). 
Sherman, E. (2019, May 31). Insurers are Going High-Tech to Mitigate Risk This Insurance Season. Fortune. Retrieved from: https://fortune.com/2019/05/31/insurance-risk-management-hurricane-season/ (last accessed 4 Dec. 2020).

Silberg, G., Mayor, T., Dubner, T., Lakshman, B., Suganuma, Y., Doshi, N., \& Anderson, J. (2020). Automotive's new reality: Fewer trips, fewer miles, fewer cars? KPMG. Retrieved from: https://advisory.kpmg.us/content/dam/advisory/en/pdfs/2020/automotives-new-reality.pdf (last accessed 4 Nov. 2020).

Sistrunk, J. (2020, November 19). Lawmakers Probe Reinsurance Plan for Future Pandemics. Law360. Retrieved from: https://www.law360.com/articles/1330192/lawmakers-probe-reinsurance-plan-for-future-pandemics (last accessed 3 Dec. 2020).

Sloan, C., Duddy-Tenbrunsel, R., Ferguson, S., Valladares, A., \& Kornfiel, T. (2020, September 16). COVID-19 Projected to Worsen Racial Disparities in Health Coverage. Avalere. Retrieved from: https://avalere.com/press-releases/covid-19-projected-to-worsen-racialdisparities-in-health-coverage (last accessed 19 Nov. 2020).

Souter, G. (2020, August 20). Broker wins ruling to escape COVID-19 business interruption suit. Business Insurance. Retrieved from: https://www.businessinsurance.com/article/20200820/NEWS06/912336202/ Broker-Swingle-Collins-\&-Associates-wins-ruling-to-escape-COVID-19-business-inte (last accessed 19 Nov. 2020).

Stanovich, C. F. (2020, June). The Coronavirus and the CGL Policy. IRMI. Retrieved from: https://www.irmi.com/articles/expert-commentary/coronavirus-and-the-cgl-policy (last accessed 19 Nov. 2020).

Swiss Re Corporate Solutions (2020). E\&O Risk Management and COVID-19. Retrieved from: https://corporatesolutions.swissre.com/dam/ jcr:c22d47cc-1186-4e2d-825a-6cd2334c1acf/EO_Risk \%20Management_COVID-19.pdf(last accessed 19 Nov. 2020).

Takagi, G., \& Yagishita, K. (2020). Principles of Disinfectant Use and Safety Operation in Medical Facilities during Coronavirus Disease 2019(COVID-19) Outbreak. Springer Nature Compr. Clin. Med., 2, 1041-1044. doi: 10.1007/s42399-020-00413-x.

Trilla, A., Trilla, G., \& Daer, C. (2008). The 1918 "Spanish Flu” in Spain. Clinical Infectious Diseases, 47(5), 668-673. doi: 10.1086/590567.

Tversky, A., \& Kahneman, D. (1981). The Framing of Decisions and the Psychology of Choice. Science, 211(4481), 453-458. doi: 10.1126/science.7455683.

Tversky, A., \& Kahneman, D. (1982). Judgment Under Uncertainty: Heuristics and Biases. In D. Kahneman, P. Slovic, \& A. Tversky (eds.), Judgment Under Uncertainty: Heuristics and Biases. Massachusetts: MIT. doi: 10.1017/CBO9780511809477.

Van Broekhoven, H., \& Hellman, A. (2006, May). Actuarial reflections on pandemic risk and its consequences. Oxford: Groupe Consultatif Actuariel Europeen. Retrieved from: https://actuary.eu/documents/pandemics_web.pdf (last accessed 25 Nov. 2020).

Ventura, T. G. (2020, August 20). Beware of COVID-19 'Name the Broker' Lawsuits. Marshall Dennehey. Retrieved from: https://marshalldennehey.com/articles/be- 
ware-covid-19-\%E2\%80\%9Cname-broker\%E2\%80\%9D-lawsuits (last accessed 19 Nov. 2020).

Verizon Connect (2020, September 8). COVID-19 Impact: U.S. Fleet Miles drop 17\%, Recovering Fast. Verizon Connect. Retrieved from: https://www.verizonconnect.com/resources/article/covid-19-fleet-data-trends/ (last accessed 4 Nov. 2020).

Visual and Data Journalism Team (2020, December 1). Covid-19 pandemic: Tracking the global coronavirus outbreak. $B B C$ News. Retrieved from: https://www.bbc.com/news/ world-51235105 (last accessed 1 Dec. 2020).

Wall, D. J., DiMugno, J. K., \& Plitt, S. (2020). Catastrophe Claims: Insurance Coverage for Natural and Man-Made Disasters. Thomson Reuters.

Walsh, M. W. (2020, August 5). Businesses Thought They Were Covered for the Pandemic. Insurers Say No. New York Times. Retrieved from: https://www.nytimes.com/2020/08/05/business/business-interruption-insurance-pandemic.html (last accessed 23 Nov. 2020).

World Bank, Press Release (2020, October 7). COVID-19 to Add as Many as 150 Million Extreme Poor by 2021. Retrieved from: https://www.worldbank.org/en/news/press-release/2020/10/07/covid-19-to-add-as-many-as-150-million-extreme-poor-by-2021 (last accessed 3 Nov. 2020). 